\title{
REVOLUCIÓN SANDINISTA Y LAS POLÍTICAS EXTERIORES DE LOS EE. UU., LA URSS Y COSTA RICA EN LAS CARICATURAS DE HUGO DÍAZ, 1974-1994
}

\author{
THE SANDINISTA REVOLUTION AND THE FOREIGN POLICIES \\ OF THE UNITED STATES, THE USSR AND COSTA RICA \\ IN THE CARTOONS OF HUGO DÍAZ, 1974-1994
}

Sofía Vindas Solano

Recibido: 06/05/2019 - Aceptado: 25/08/2019

\begin{abstract}
Resumen
Este artículo tiene por objetivo analizar de qué manera caracteriza Hugo Díaz en sus caricaturas, las acciones de actores vinculados a Costa Rica, los EE. UU. y la URSS durante los eventos de la Revolución sandinista. Las obras captan una lectura específica que realiza el artista sobre su contexto y sobre cómo interpreta las políticas exteriores de estos actores durante la Guerra Fría con relación al conflicto en Nicaragua, entre 1974-1994. A su vez, se analizan los elementos técnicos, estéticos e iconográficos de las caricaturas y los personajes que se representan. Estas obras evidencian una crítica del artista, sobre la pretendida postura de neutralidad costarricense.
\end{abstract}

Palabras clave: caricatura, arte visual, humor, ilustraciones, URSS, EE. UU., política exterior, Centroamérica, relaciones internacionales.

\begin{abstract}
The purpose of this article is to analyze how Hugo Díaz characterizes in his cartoons the actions of actors linked to Costa Rica, USA and the USSR during the events of the Sandinista Revolution. These works capture a specific reading that the artist generates about his context and how he interprets the foreign policies carried out by these actors during the Cold War in relation to the conflict in Nicaragua, between 1974-1994. At the same time, the technical, aesthetic and iconographic aspects of the cartoons and the characters that are represented are analyzed. These works are evidence of the criticism on the alleged position of Costa Rican neutrality.
\end{abstract}

Keywords: caricature, visual art, humor, illustrations, USSR, USA UU., Foreign policy, Central America, international relations. 


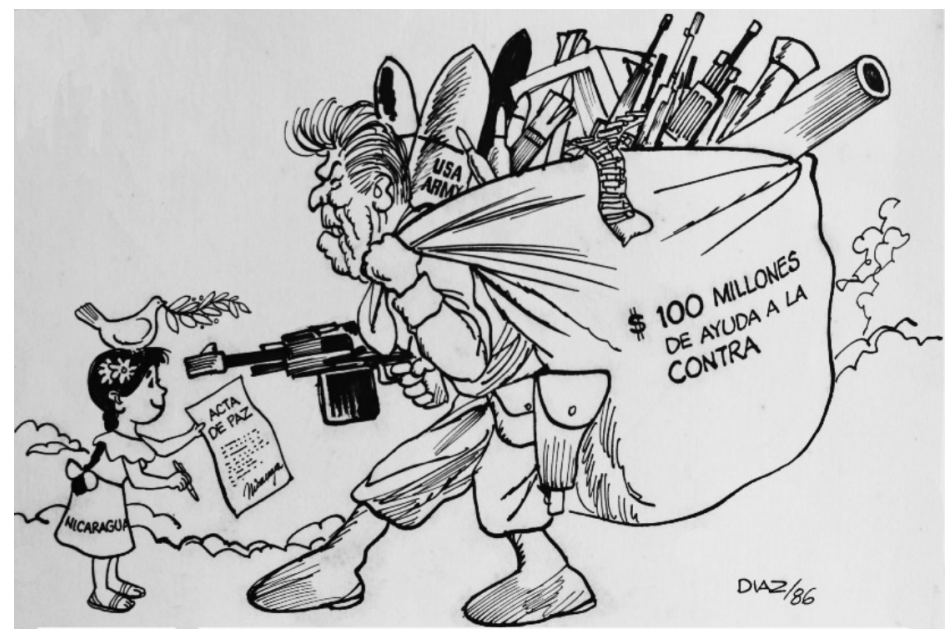

"\$100 millones de ayuda a la contra". Hugo Díaz, 1986. Semanario Universidad

Esta investigación tiene por objetivo analizar de qué manera caracteriza Hugo Díaz en sus caricaturas las acciones de actores vinculados a Costa Rica, los EE. UU. y la URSS durante la Revolución sandinista, para conocer cómo se representan las políticas exteriores que llevan a cabo estos países en el contexto de la Guerra Fría con relación al conflicto en Nicaragua, entre 1974-1994. Gracias al acceso concedido por los MuseosUCR a la colección que el artista mismo le donó a la Universidad de Costa Rica se tuvo acceso al acervo de Hugo Díaz. Actualmente, el museo cuenta con más de cuatro mil caricaturas catalogadas. El Semanario Universidad posee caricaturas del artista también, y estas obras no se encuentran disponibles al público ni están incluidas en la colección de MuseosUCR. Debido al limitado acceso que se tiene al corpus de dibujos del Semanario Universidad, este no se pudo revisar para esta investigación.

En términos de la delimitación espacial, se analizará el contexto de la Revolución sandinista no solamente por la proximidad del conflicto a la realidad costarricense, sino por declaraciones mismas del artista Hugo Díaz: para él, hablar sobre ese conflicto fue una labor importante dentro de su producción artística. A razón de esto el artista comentó "Hubo un tiempo en que apoyé mucho al hombre sin tierra, a los huelguistas, la Revolución sandinista y la salvadoreña, a los niños y, en general, cualquier cosa contra la corrupción" (Sánchez Molina, 2016, 173). Como los demás artistas de la época, Díaz siguió de cerca el conflicto en suelo nicaragüense que estalló el 19 de Julio de 1979 y parece haber considerado sus caricaturas como una manera no solo de ser testigo, sino también protagonista de los hechos como ciudadano de un país vecino. Como se verá en el análisis de las obras, Díaz constantemente utiliza humor y sarcasmo 
para llamar la atención a temáticas específicos del conflicto, en especial los abusos de poder de los líderes políticos.

La delimitación temporal responde no solo al periodo en que se da dicha revolución: 1979-1990. Ya que, luego de la revisión de las caricaturas se encontró que en el acervo de la colección de Hugo Díaz de los MuseosUCR, existen obras que se remontan a mediados de la década de 1970, cuando Díaz ya comenzaba a ilustrar el conflicto social que vivía Nicaragua, frente a Anastasio Somoza Debayle. Por eso, se encontró un corpus de caricaturas desde 1974, por ello se extiende la delimitación hasta esa fecha. También hay caricaturas valiosas que se recopilaron en los siguientes 4 años después de que el Frente Sandinista pierde las elecciones en 1990 frente a la coalición liderada por Violeta Chamorro, por lo que se cierra el análisis en 1994.

En términos metodológicos, las caricaturas fueron analizadas con base en la propuesta de la teoría de la imagen de Villafañe (1985) y la operacionalización de esta teoría propuesta por Fernández Chaves, en El análisis de contenido como ayuda metodológica para la investigación (2002). El objetivo de las imágenes es el de sintetizar, hiperbolizar y dotar de contenido histórico eventos, acciones y a actores puntuales, los cuales el artista pone a interactuar en sus caricaturas. Para poner en práctica el análisis de contenido en las caricaturas se confeccionó la siguiente matriz metodológica, con la que se revisó la colección de Díaz en torno a la temática (Tabla 1). 


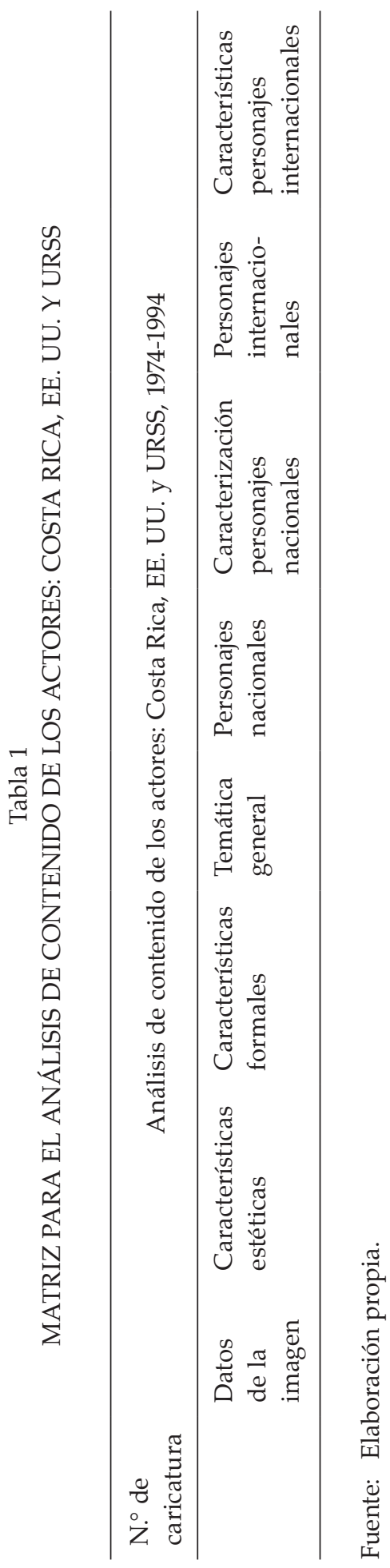


Para dar respuesta a la pregunta generadora, la investigación está organizada en los siguientes apartados: un primer apartado que analiza aspectos técnicos y estéticos sobre la obra de Hugo Díaz, seguidamente se analizan los actores y temáticas presentes en las caricaturas sobre la Revolución sandinista. Este apartado tiene como fin evidenciar que los personajes más retratados en el corpus de obras recopilado son aquellos vinculados a las cúpulas del poder, y por ende la temática que más analiza Díaz en estas imágenes es la caracterización de las políticas exteriores de EE. UU., la URSS y Costa Rica durante el conflicto de la Guerra Fría y la Revolución sandinista específicamente. Seguidamente, en el siguiente apartado se analizan 15 casos o caricaturas para ampliar en el análisis sobre las acciones y políticas exteriores de cada actor en el contexto de estudio.

\section{Sobre la técnica y la estética de la caricatura política en Hugo Díaz}

La riqueza de la caricatura es que en su simplicidad, esta desnuda al retratado de sus máscaras, le presenta en su esencia: con sus defectos y sus características fundamentales expresadas mediante la hipérbole. Para Pérez Yglesias: "el chiste político como práctica de comunicación, se ocupa de la actualidad, de un "aquí y ahora", de figuras conocidas y acontecimientos sociales y va dejando una clara huella en la historia, en el imaginario colectivo" (187). Las caricaturas de Díaz interpretan hechos históricos de manera integral y clara para que el lector-receptor de las imágenes pueda identificar fácilmente de quién se trata y de qué se trata.

El aspecto pragmático de la imagen para su fácil lectura es una convicción que el mismo Díaz compartió y promovió. Así lo afirmó el artista en una conferencia que ofrece en 1992, en la Sede de Occidente de la Universidad de Costa Rica, cuando dijo:

cuando digo que soy pragmático, yo lo que trato de decir es que yo quiero mis caricaturas sean muy claras, que no sean una cosa de doble sentido, ni una cosa que haya que adivinarla. Sino que sea muy directa, que todo mundo la pueda entender, porque si uno quiere dar un mensaje debe ser muy claro. $Y$ como mi oficio es el de caricaturista yo trato que mi mensaje sea humorístico (Díaz, 1992).

En términos temáticos, en esa misma conferencia, Díaz afirma que los temas que más ocupan su obra son los procesos históricos que afectan a Costa Rica, sus gobernantes, nuestra relación con el resto del mundo, con especial énfasis en Centroamérica y Latinoamérica. Para Hugo Díaz "La caricatura no debe estar ajena a lo que sucede en el país... yo no podría ser un caricaturista sin compromiso" (Sánchez Molina, 2016). En sus entrevistas el artista manifestó reiteradamente la importancia de analizar a Costa Rica vinculada con el resto del continente, no aislada de los problemas de los países vecinos, ya que la comparación de nuestros contextos permite evidenciar patrones de injusticia y problemáticas, así como de cultura e historia compartida (Díaz, 1992). Además, afirmó que el tema de la autonomía frente a las influencias culturales y económicas 
de los Estados Unidos fueron un tema predilecto en su trabajo creativo. Este punto es importante tenerlo en cuenta, en especial al revisar los casos de estudio para el presente análisis, puesto que el artista utiliza la figura del Tío Sam reiteradamente, como recurso didáctico para realizar una lectura del ajedrez geopolítico que viven los países de la región. Este recurso tiene una larga data en la caricatura internacional: la figura del Tío Sam como comentario sobre el "imperialismo yankee", es un ícono bastante utilizado por los caricaturistas centroamericanos en particular, entre ellos Díaz.

En este sentido, la presencia imperialista de Estados Unidos queda bien clara en las obras que realiza Díaz sobre la Revolución Sandinista y el papel que juega Costa Rica en ese proceso. En ellas encontramos una lectura hiperbólica sobre la cruel y aplastante presencia del Tío Sam en la vida política de los países centroamericanos. La complejidad y riqueza de estas obras reside no solo en su enfoque satírico sino en el componente contextual de su lectura, lo que las hace fácil de entender e interpretar para el lector.

Díaz recibió por su labor tres altos galardones costarricenses: el Premio Nacional de Periodismo Joaquín García Monge (1976), el Premio al Periodismo Pío Víquez (2000), así como el Premio Aquileo J. Echeverría en Artes Plásticas, en 1996. Publicó sus obras en varios periódicos algunos de ellos fueron: El Pueblo, El Semanario Universidad y La República, en donde trabajó a lo largo de más de veinte años. Quienes publicaban tanto en opinión como en ilustración en el Semanario Universidad "se convirtieron, en ese sentido, en emisores de un mensaje público que mereció, o no, una respuesta, pero siempre tratando de influenciar o incluso de determinar la forma en que se debía interpretar la coyuntura vivida" (Díaz Arias 192). Durante la década de los setenta, Díaz está fuertemente vinculado a actividades y concursos relacionados al humor gráfico nacional e internacional (Flores Valle 168): El Salón Anual de la Caricatura Noé Solano (1970), El Salón Internacional de la Caricatura en Montreal (1972), y el Premio Nacional Joaquín García Monge del 76.

En todas las obras del artista, el texto antecede a la imagen, lo iconográfico se subordina a lo lingüístico. Según Pérez Yglesias, el artista le relató su proceso de creación de las imágenes diciendo:

primero imagino mentalmente el texto...luego lo dibujo a lápiz y finalmente lo entinto. Una vez escogido el tema, tardo un día completo para darle forma, primero hago el guion del diálogo y luego lo ilustro (16).

En cuanto al proceso técnico que siguió el artista, Díaz comentó que al comenzar su carrera artística en los cuarentas y posteriormente hasta los cincuentas, era poco fácil exponer y publicar obras por el alto costo que involucraba la realización de la caricatura. Para que se pudiera publicar la obra, Díaz explica (1992) que primero debía realizarse un "clisé" o "cliché": un grabado en metal hecho en zinc donde se dibuja la caricatura, para luego ser impresa en el periódico. Esta técnica se utilizaba para la impresión tipográfica en papel típicamente, mediante el uso de placas en un proceso 
complejo de impresión. Por ejemplo, los textos publicados en prensa eran hechos en plomo, similar al de una máquina de escribir.

La caricatura realizada en zinc según Díaz formaban un relieve, "las líneas quedan en relieve y lo que es blanco queda más abajo, actuando como un sello" (1992). Esta era la técnica que hacía que el proceso fuera costoso. Entre los sesentas y setentas irrumpe en el medio artístico la técnica del offset, que hace uso de un sistema de planchas litográficas para la reproducción de las imágenes. Así, el proceso se abarata, por lo que publicar una caricatura llega a tener el mismo costo que la impresión de los artículos. Esta nueva técnica facilitó el acceso de artistas a la publicación en prensa de sus imágenes. Las caricaturas acá analizadas ya hacían uso de ese proceso, que aunque más eficiente, tomaba tiempo entre la creación del guion, el proceso de preparación de colores e impresión final.

Con relación a su contenido, los caricaturistas como Díaz poseen un fuerte carácter didáctico y reflexivo. Para explicar esto, María Pérez Yglesias señala que ante la sobriedad del texto y, en general, de su técnica formal, Díaz carga la imagen de una serie de recursos asociados a la ironía para transmitir su mensaje. Así:

Contrariamente al texto escrito, donde el tono o el gesto irónico deben ser explicitados lingüísticamente o señalados a través de la puntuación, la historieta [y la caricatura] posee los recursos del dibujo y de la tipografía: el tamaño y el grosor de las letras, el trazo de la línea, la forma del balón, unidos a los gestos de los personajes pueden fácilmente reforzar la ironía o señalarla como tal (17).

En general las obras de Díaz son sobrias, las líneas son claras y delgadas. El artista aprovecha mucho la síntesis y la exageración de las figuras y sus facciones, lo que es típico del formato de la caricatura para que el público reconozca fácilmente los personajes. Este es un recurso fundamental, donde la imagen

satírica se basa en la comparación cómica, es decir, en la creación de tipos convincentes basados en un conocimiento anterior a la dimensión estrictamente fisiológica de la expresividad emocional (Román 179).

Las caricaturas analizadas se publicaron entre 1970 y 1990 principalmente en dos periódicos: El Pueblo y el Semanario Universidad. La mayoría de las imágenes encontradas para esta investigación aparecieron en El Pueblo, a pesar de que muchas de las caricaturas no tienen datos sobre dónde fueron difundidas. Díaz publica bajo diversos seudónimos: Lalo, Díaz, Pancho, Tuto, dependiendo del medio en el que publica y el estilo que usa (Pérez Yglesias). Ana Sánchez Molina afirma que esto lo hizo con el propósito de "dar un dibujante "exclusivo" a cada publicación" (Sánchez Molina, 2017).

En términos formales las ilustraciones de Hugo Díaz presentan dos formatos dependiendo de su función: en algunos casos siguen el formato de la historieta: cargadas de contenido en el que los actores conversan. En otras instancias son caricaturas puntuales 
sobre un evento o situación específica, para ilustrar escenas concretas. Parece ser que el artista utilizó ambos formatos para permitirse profundizar en los temas que consideró pertinentes, aunque mediante las caricaturas produjo comentarios más sintéticos.

Con respecto a los rasgos estilísticos de la obra de Díaz, la tridimensionalidad de sus figuras, así como el fuerte carácter gráfico de su trabajo son centrales en sus obras, herencia de otros influyentes artistas como Noé Solano, Francisco Hernández, entre otros. En las obras de Díaz, "la línea de contorno es un ingrediente principal en la delimitación de la figura. Esto, como en casi todos sus dibujos, está condicionado por su preferencia por la técnica del dibujo en plumilla" (Anglin Fonseca 91). Predomina así mismo en su trabajo, el uso de la línea curva que "aporta unidad y ritmo a la composición" (Anglin Fonseca 93) del artista. Todas estas características describen claramente las figuras que acá se analizan de Díaz. La importancia de estos rasgos es que mediante su estética dinámica y sobria se crea un universo iconográfico, que hace que Díaz se convierte en un artista influyente y cuyas obras se tornan memorables así como fáciles de reconocer y entender.

\section{Actores y temáticas vinculadas a las políticas exteriores de Estados Unidos, la Unión Soviética y Costa Rica en las caricaturas de Hugo Díaz}

Es importante referirse a actores específicos antes de analizar los casos, ya que autores como María Pérez Yglesias ya han propuesto una suerte de nomenclatura sobre los personajes que se desprenden de la iconografía que construye Díaz en sus imágenes. En ellas, Díaz caracteriza "tipos sociales" así como actores asociados a posturas ideológicas determinadas, los cuales ayudan a entender las características acá analizadas. A esos primeros actores, la autora les llamó "personajes prototípicos" (1983), a los segundos "personajes fijos". La figura del "pueblo", por ejemplo, es un personaje prototípico en Díaz, que aparece en el presente corpus de caricaturas. En este sentido, el pueblo está representado por "aquellos marginados al poder o que ponen su poder al servicio de las mayorías" (Pérez Yglesias 22).

Según las caricaturas acá analizadas, los personajes que más utiliza Díaz con relación a la Revolución sandinista son "personajes fijos". Es por esto que en esta investigación se analizan detenidamente las políticas exteriores de los países reseñados, ya que los "personajes fijos" en Díaz corresponden a actores:

casi siempre reales y pertenecen al mundo de la politica, o a cierto estatus social que les permite ser noticia... los personajes reales que tipifican el poder (económico, espiritual, político o cognitivo, etc.) sustentan un discurso más o menos estereotipado que se va a desenmascarar en él mismo (22).

En total sobre la Revolución sandinista, se encontraron alrededor de 120 caricaturas específicas para el periodo. Algunas de los temas que comentó Díaz con relación a la figura de EE. UU., la URSS y Costa Rica son los siguientes. 
Con relación a los EE. UU., Díaz asoció la política y posición del país a través de actores claves vinculados a la presidencia del momento. Ejemplo de ello es la figura de Jimmy Carter. Se encontraron unas dos decenas de caricaturas sobre este actor, presidente de los EE. UU. entre 1977-1981. Las temáticas de esas imágenes tienen que ver con la relación de EE. UU. con el Medio Oriente, en relación con el asesinato del Padre Romero, con relación a Nicaragua y la Revolución sandinista, también sobre las dictaduras de América del Sur; con relación a Cuba, y con relación a la famosa defensa de los derechos humanos. emprendida por Carter con relación al Canal de Panamá.

Con relación a Ronald Reagan, se encontraron alrededor de dos docenas de caricaturas del presidente de EE. UU. entre 1981-1989: las temáticas tratadas tienen que ver con la política exterior del presidente, con relación a su vínculo con Gorbachov, sobre Nicaragua y la Revolución sandinista, con relación al Medio Oriente en especial Irán e Israel y con relación a Cuba. Así mismo, se representó a George H. W. Bush quien fue presidente de EE. UU. entre 1989-1993, se encontraron únicamente 2 caricaturas con relación a este actor, una sobre el conflicto en Irán y otra sobre el tema presente.

De igual manera, Hugo Díaz representó otros actores institucionales asociados a dicha potencia, ejemplo de ello es que retrató a la CIA, el FBI entre otros. Las caricaturas con frecuencia tenían que ver con el contexto Centroamericano y con temas internacionales o de América del Sur. En todas estas caricaturas otro actor asociado a EE. UU. que aparece a lo largo del periodo $-\mathrm{y}$ junto a los presidentes anteriormente mencionados- es la figura del Tío Sam.

Con relación a la URSS, existen considerablemente menos actores representados: Aparece la figura de Mijaíl Gorbachov, líder de la Unión Soviética entre 1990-1991, quien es la única figura retratada por Díaz en las caricaturas encontradas. De él se encontraron 4 caricaturas para el periodo y posterior al periodo, de hecho 3 de las 4 caricaturas corresponden a finales del siglo XX, solamente 1 caricatura hace alusión a la Guerra Fría en la que se retrata Gorbachov junto con Reagan.

Otros líderes fundamentales del proyecto soviético aparecen por ejemplo: para 1992 Díaz crea una caricatura con la figura de Lenin junto con Gorbachov; en esta caricatura Gorbachov aparece vistiendo una camiseta con la inscripción "Yo defendiendo los valores socialistas", mientras se devora una hamburguesa, típica imagen de la cultura norteamericana (Figura 14).

Sobre los actores vinculados a Costa Rica, al comentar sobre los eventos sociopolíticos del momento Díaz representa en su mayoría a los líderes políticos del país: Rodrigo Carazo (presidente de 1978-1982), Luis Alberto Monge (1982-1986), Óscar Arias (1986-1990) y Rafael Ángel Calderón (1990-1994).

Para el presente análisis solamente se tomaron en cuenta personajes vinculados con política exterior del país: como Ministros y Presidentes. Debe mencionarse que Óscar Arias, presidente entre 1986-1990 y Rafael Ángel Calderón Fournier presidente entre 1900-1994, no son representados con relación a lo que sucede en Nicaragua. 
Únicamente se registró una caricatura en la que Arias se representa acercándose a la OEA para conversar sobre la necesidad de frenar intentos similares a los de Somoza en la región, en décadas posteriores. Estos dos presidentes se representan en muchas caricaturas, sin embargo, solo en relación con las tensiones latentes entre Costa Rica y la OEA, por lo que este tema queda abierto a futuras investigaciones.

La figura de "La Contra" en el trabajo Hugo Díaz es fundamental, puesto que en las imágenes el artista claramente presenta su postura, al considerar que dicho movimiento contrarrevolucionario fue la operacionalización de la política exterior anticomunista de los EE. UU. mediante la CIA, en el suelo costarricense. Díaz critica este hecho en más de media docena de caricaturas que abarcan el periodo. Según Dirk Kruijt, hacia mediados de los ochentas los políticos costarricenses temían "ante la amenaza de los nicaragüenses que querrían compartir su gloriosa Revolución con el resto de Centroamérica, incluidos nosotros", el gobierno de Costa Rica dio autorización para que la Contra de (Edén) Pastora operase libremente a lo largo de su frontera con Nicaragua, con una fuerza de 7.500 efectivos" (71). De esta manera, el apoyo de políticos como Ronald Reagan, sería fundamental en el sostenimiento de esta situación.

Sobre algunos actores nicaragüenses con relación a la Revolución sandinista, se encontraron más de cien caricaturas. En especial sobre la figura de los Somoza, a quienes Díaz parece haber retratado más que a cualquier otro actor de ese país. Específicamente sobre Anastasio Somoza Debayle se encontraron casi 40 caricaturas. Se buscaron también imágenes con relación a la familia Chamorro y Violeta Chamorro para completar los últimos años de la revolución. No obstante, no se encontraron más de 5 caricaturas sobre el proceso de transición democrática de los años noventa en Nicaragua, que no hacían referencia a la Revolución o al tema del presente análisis.

\section{Análisis de 15 casos entorno a la Revolución sandinista y la obra de Hugo Díaz en la prensa costarricense}

La Revolución sandinista como movimiento de insurrección, respondía a la dictadura dinástica de los Somoza que como familia habían gobernado a Nicaragua por décadas mediante una dictadura. Además, el movimiento recuperó el elemento de la lucha antiimperialista que libró Augusto Sandino en las primeras décadas del siglo XX. Para Edelberto Torres-Rivas, la historia nicaragüense es "la crónica de una imposibilidad" (Torres-Rivas 123): una historia que marcada por el fracaso del proyecto liberal del siglo XIX, la intervención norteamericana en las primeras décadas del siglo XX y

la entrega del país a la familia Somoza y a la Guardia Nacional durante 43 años (1936-1979) en que aquélla y ésta prolongaron la intervención extranjera y destruyeron todo intento de consolidación de un Estado nacional moderno e independiente (Torres-Rivas 123). 
Tal y como lo dice este autor, actor clave de este proceso ha sido el gran hermano del Norte: Los Estados Unidos, cuyo apoyo,

firme sostén de la dictadura termina el 16 de julio. Somoza II huye a Miami con varios generales y la Guardia Nacional, creatura norteamericana para combatir a Sandino se desploma frente a los sandinistas, que entran en Managua el 19-VII-1979. La revolución había triunfado (Torres-Rivas 111).

Analizar las acciones y la política exterior puesta en práctica por estos actores a través de las caricaturas, sirve como manera de conocer no solo la opinión del artista mediante su obra, sino como fuente histórica de cómo la sociedad costarricense vivió el desarrollo del movimiento sandinista en Nicaragua y aunado a ello, el impacto sociopolítico de la Guerra Fría en la región. A su vez, los periódicos de la época en donde las caricaturas se publican funcionan como espacios de difusión y debate en la formación de la opinión de sus lectores. Investigadores como Jorge G. Castañeda ya han anotado que

en América Latina los intelectuales suelen articular demandas democráticas a través de la prensa, la academia, el Gobierno y desde el exterior. Nos referimos, en efecto, a una especie de "élite cultural" (Altamirano 9).

En el caso costarricense dicha élite, menciona Díaz Arias, "tiene la posibilidad de verter sus análisis de la realidad por medio de, precisamente, la prensa" (192). Por su parte, para Gantús:

Las caricaturas políticas de la prensa periódica permite también seguir el curso de los acontecimientos, tomarle el pulso a las tensiones políticas y descubrir los asuntos que estaban en el lugar central y los personajes que ocupaban papeles estelares en un lugar y momento determinados (5).

Las caricaturas e historietas de Díaz son interesantes testigos simbólicos y fuentes esenciales que retratan y comentan la época en la cual fueron creadas.

La relación entre Centroamérica y los Estados Unidos se caracteriza por una sostenida relación de tensiones y presiones políticas tanto a través de presencia militar, presión económica y/o diplomática. Posteriormente a la promulgación de la Doctrina Monroe y a la Segunda Guerra Mundial, cualquier conflicto generado por un movimiento de tinte comunista en Centroamérica, era peligroso para los Estados Unidos puesto que evidenciaba la vulnerabilidad geopolítica de esta potencia frente a la URSS. A su vez, hacía inmediata y necesaria una reacción por parte del Norte, frente a la amenaza del proyecto soviético en el rango de dominio territorial de los Estados Unidos. Un evento similar ya había sucedido unas dos décadas antes, cuando otro triunfo visto como "comunista" ganara terreno en otro país de la región: esta 
fue la "Revolución de Octubre" de 1944 en Guatemala y la consecuente llegada de Arévalo y Arbenz al poder. Si bien estos gobiernos no fueron comunistas, sus políticas socio-económicas, en especial el proyecto de reforma agraria eran vistas como amenazantes para EE. UU. Como consecuencia Arbenz sufrió un golpe de Estado respaldado por EE. UU.

Con antecedentes como estos, durante la Revolución en Nicaragua, los Estados Unidos habían buscado evitar que el movimiento tomara fuerza a toda costa. Según Powaski, el gobierno de Carter había ejercido presión sobre Somoza, para que efectuara mejoras en términos de derechos humanos. Así, "en junio de 1979, cuando la caída de Somoza parecía inminente, el gobierno de Carter incluso trató de persuadir a la Organización de Estados Americanos a intervenir en Nicaragua para impedir la inevitable victoria sandinista" (Powaski 271).

Figura 1

“TACHO”, 1976, TINTA CHINA EN CARTULINA

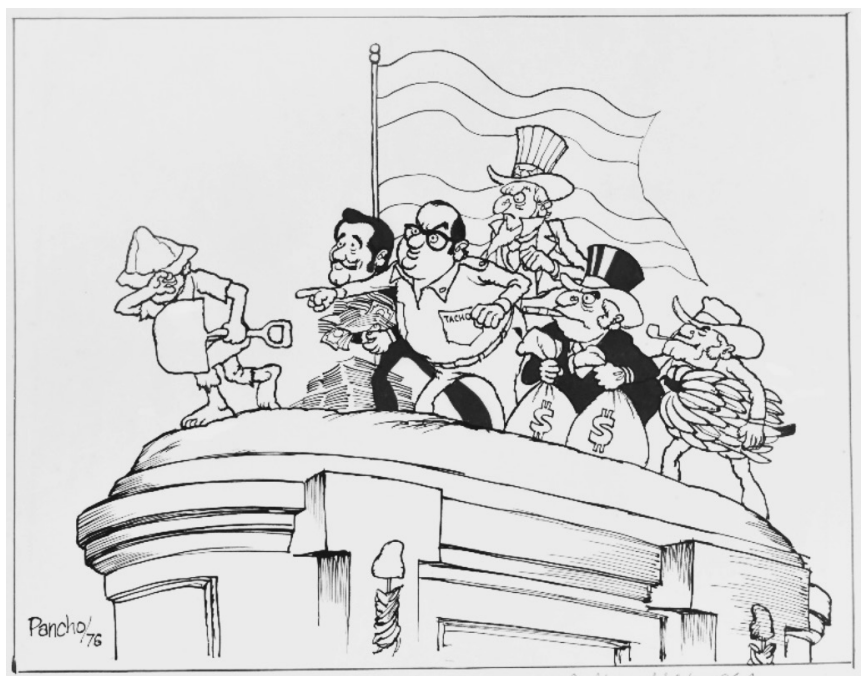

Fuente: UCR-CHD-2906, Museos UCR.

La familia Somoza aparece con frecuencia en la colección de Hugo Díaz. ${ }^{1}$ Alrededor de más de una centena de caricaturas tienen que ver con la dinastía de los Somoza, tanto padre como hijo. En estas caricaturas el artista presenta líneas sobrias y el uso profuso del contraste entre espacios negros y claros para crear una imagen limpia y fácil de leer para el receptor.

Un buen ejemplo de lo anterior es la Figura 1, la cual representa una síntesis del pensamiento de Díaz en relación con la dinastía de los Somoza. En ella miramos una simple y fuerte imagen de lo que es el Monumento Nacional de Costa Rica, monumento 
develado en 1895 dedicado a rememorar la lucha contra los filibusteros liderados por William Walker en Nicaragua, en la Campaña Nacional de 1856. En esta imagen sin embargo, la historia es completamente distinta, a diferencia de lo que se puede mirar en el monumento donde de las figuras de las amazonas (5 mujeres que representan a Centroamérica) expulsan a William Walker de la región, en esta caricatura Díaz coloca a Somoza, acompañado de un grupo de hombres amedrentando a un personaje que tapa su cara y lleva un chonete en la cabeza (un sombrero típico costarricense). Este tipo de representación del chonete en una persona descalza es la imagen de un personaje prototípico (según la clasificación de Pérez Yglesias) que utiliza Díaz en sus caricaturas, para representar la figura del "pueblo". El chonete es símbolo en Díaz de sencillez y la humildad; así, Díaz "consciente de ello, acude a símbolos arquetípicamente asociados a lo nacional -la carreta, la pala, el campesino-, a sabiendas de que generarán cercanía en el lector" (Flores Valle 185).

Somoza claramente distinguido por su cabeza semicalva, sus anteojos grandes y negros y su bigote, está acompañado por el Tío Sam, más dos figuras de hombres cargando dólares y bananos representando los poderes latifundistas de la región. El último integrante de la agresión contra el "pueblo" sería el entonces Ministro de Seguridad Pública costarricense Mario Charpentier Gamboa, quien más adelante sería el encargado de supervisar la sospechosa actividad de Somoza y la organización de La Contra en la frontera Norte del país. Charpentier aparece en varias imágenes siendo criticado por Hugo Díaz por su falta de firmeza con relación a la situación de Nicaragua durante el mandato de Daniel Oduber. En algunas imágenes Díaz incluso insinúa que Charpentier tiene una actitud servil para con Somoza.

La anterior imagen es una excelente síntesis para entrar a analizar el corpus de imágenes de Hugo Díaz. En general Somoza Debayle es representado como un personaje extravagante y caprichoso, sediento de sostenerse en el poder dinástico que su padre le había legado. La representación de Díaz es consistente con lo que reconstruye a través de testimonios Mariela Gatica, sobre la figura de Somoza, y la razón de por qué ya para finales de la década de los setenta el líder nicaragüense no era bien visto por amplios sectores de la población en Nicaragua y Centroamérica. Para la autora

el temor ante la expansión del comunismo o las ideas de izquierda en general, asociado al libertinaje de personajes como Somoza, quien estaba dispuesto a entregar el país a la nación extranjera, desató una lucha que terminó siendo una disputa moral, politica e ideológica, sobre la soberanía del país. Es por este motivo que la idea de liberación nacional, no solo es defendida por los sectores más radicalizados, sino por un espectro más amplio y con razones heterogéneas al respecto, pero que sin embargo logran dar al curso de liberación nicaragüense una continuidad con respecto a las luchas independentistas libradas por Sandino (Gatica 2).

El anterior comentario se puede leer a la luz de la Figura 1, donde claramente Somoza es asociado con una noción de intromisión del capital extranjero y de depredación 
de los recursos de la nación. Además, este argumento apoya también metodológicamente la decisión de estudiar actores precisos de la palestra internacional vinculados a favor y en contra de la Revolución sandinista, ya que Díaz no parece caracterizar mucho al Frente Sandinista de Liberación Nacional sino que, por la naturaleza de la caricatura, escoge representar en general, a personajes fáciles de reconocer asociados al movimiento: Carlos Fonseca (uno de los fundadores del Movimiento Sandinista) principalmente y el sacerdote Ernesto Cardenal por ejemplo. El artista dedica más tiempo y espacio a representar a los protagonistas del conflicto y a los poderes internacionales vinculados con la Guerra Fría.

Figura 2

“PLUTARCO LUCHA POR LA LIBERACIÓN DEL PUEBLO NICA”, 1978, TINTA CHINA EN CARTULINA

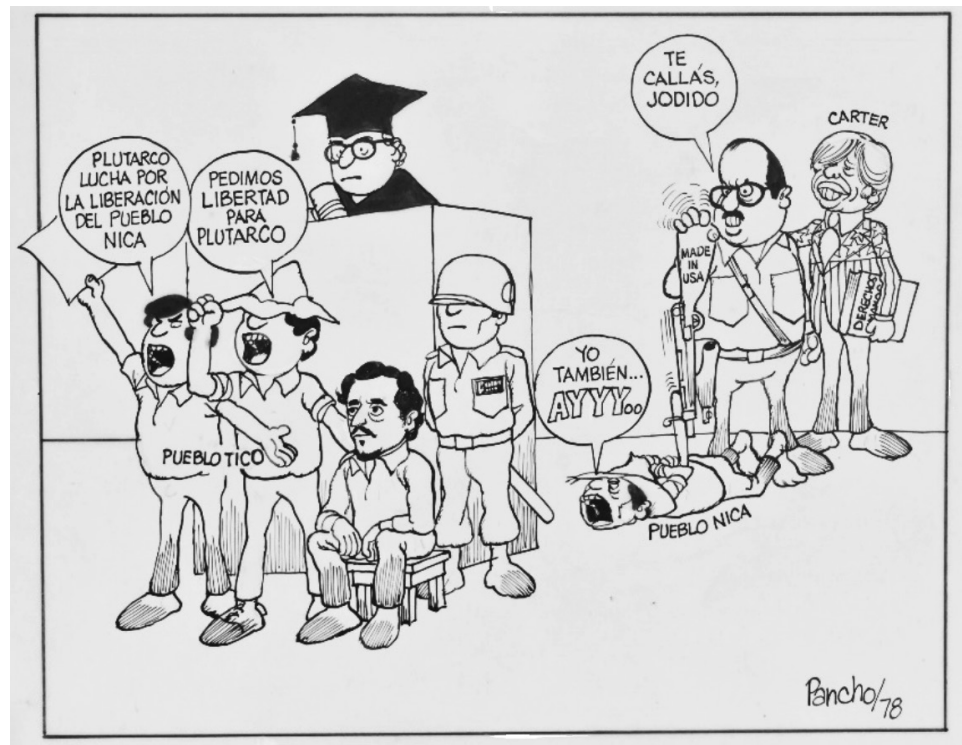

Fuente: UCR-CHD-2953, Museos UCR.

A continuación, en la Figura 2 de 1978, Díaz representa a Plutarco Hernández combatiente del Frente Sandinista de Liberación Nacional (FSLN) y para entonces comandante de la revolución y miembro de la Dirección Nacional sandinista hasta marzo de 1979. Hernández hacia mediados del año setenta y ocho había sido enjuiciado por su involucramiento al tratar de poner en libertad a Humberto Ortega Saavedra líder sandinista preso en suelo costarricense (Brealey 16). Esta caricatura muestra a personajes específicos como Somoza, Jimmy Carter, y el mismo Hernández, siendo acompañados por estas figuras con chonete, que representan por un lado el pueblo tico pidiendo el indulto para Plutarco, mientras a Somoza se encuentra pisoteando al "pueblo Nica". 
El entonces presidente de los EE. UU. se limita a sonreír y cargar un libro con la inscripción "DD. HH." o Derechos Humanos. De esta manera una y otra vez Díaz hará alusión a la conocida política de supuesta promoción de los derechos humanos de la administración de Carter. Sin embargo como se verá más adelante Díaz es crítico de esta postura, porque si se mira detenidamente el arma con el que Somoza mantiene en el suelo al "pueblo nica", esta lleva una inscripción que dice "Made in USA": claramente haciendo alusión a la contradictoria postura de los EE. UU. quienes durante la Guerra Fría reiteradamente sostuvieron una política de no intervención, mientras que al mismo tiempo financiaron la militarización de movimientos anticomunistas, y en el caso de la Revolución sandinista el movimiento de La Contra. En los albores de la década de los ochenta, la tensa relación entre Nicaragua y los Estados Unidos estaba cerca de un punto de ruptura inminente, cuando los sandinistas comienzan a enviar ayuda a los revolucionarios de El Salvador, según Powaski:

Washington respondió proporcionando de forma encubierta hasta un millón de dólares a las fuerzas antisandinistas de Nicaragua, la llamada "contra". Poco antes de abandonar la Casa Blanca en enero de 1981, Carter estudió la posibilidad de cortar toda la ayuda norteamericana a Nicaragua. Sin embargo, dejó la decisión a su sucesor, Ronald Reagan, que no sólo interrumpiría dicha ayuda, sino que, además, convertiría el derrocamiento del gobierno sandinista en una obsesión personal (272).

Por la naturaleza de la caricatura -en donde las figuras deben representar sintéticamente eventos históricos complejos-, es evidente que como recurso discursivo, para Díaz era más práctico identificar la postura de los EE. UU. con relación a las diversas administraciones de los presidentes. Jimmy Carter como ya se mencionó aparece como una figura sonriente. En algunas ocasiones Carter se representa sosteniendo una bandera mientras sonríe, o sosteniendo en alto sus dedos índice y medio en alto y los demás dedos cerrados en un puño, haciendo el gesto de paz con su mano o "peace sign" de la época.

El objetivo de construir este tipo de fisonomías tan particulares en los personajes retratados es una práctica usual en la construcción de "tipos sociales" en el arte de la escritura, especialmente con relación a la literatura costumbrista. Para Dorde Cuvardic, esto se utiliza para

definir el carácter moral del individuo (etopeya) a partir de sus atributos físicos (prosopografía). Sus premisas son las siguientes: 1) Hay una correspondencia entre la apariencia física (cada parte del cuerpo humano) y el carácter moral de la persona; y 2) una parte del cuerpo humano puede representar al conjunto y constituirse en base para hacer la caracterización global moral del individuo. El rostro, en estas circunstancias, se convierte en la parte más representativa del conjunto, el cuerpo humano (38). 
La apariencia física de Carter en las imágenes de Hugo Díaz, corresponden en general con el "carácter moral" de las políticas de dicho presidente quien promovió, no sin contradicciones, una postura internacional orientada hacia el respeto de las garantías civiles. En términos de política exterior, Carter tuvo un discurso que insistía en la necesidad de subrayar la importancia de los derechos humanos para encaminar a los gobiernos hacia reformas democráticas. Es por esto que Díaz le retrata una y otra vez como un actor de mediación, sonriente y con pocos ánimos de pelear. Esto se debe a que:

"The Carter administration, reacting against the calculating realpolitik of Henry Kissinger, hoped to place human rights at the center of its foreign policy... Carter's human rights policy did not necessarily contradict the American Cold War imperative to support anti-communist governments. The goal was not to undermine authoritarian governments, but to inspire gradual reform in those governments" [La administración de Carter, reaccionando contra la "realpolitik" calculadora de Henry Kissinger, esperaba colocar los derechos humanos en el centro de su política exterior... La política de derechos humanos de Carter no necesariamente contradecía el imperativo estadounidense de la Guerra Fría de apoyar a los gobiernos anticomunistas. El objetivo no era minar los gobiernos autoritarios, sino inspirar reformas graduales en esos gobiernos] (Wilsman 10).

Para ejemplificar las palabras de Wilsman, tómese en cuenta la Figura 3.

Figura 3

MADE IN PLUTARCO LUCHA POR LA LIBERACIÓN DEL PUEBLO “NICA”, 1978, TINTA CHINA EN CARTULINA

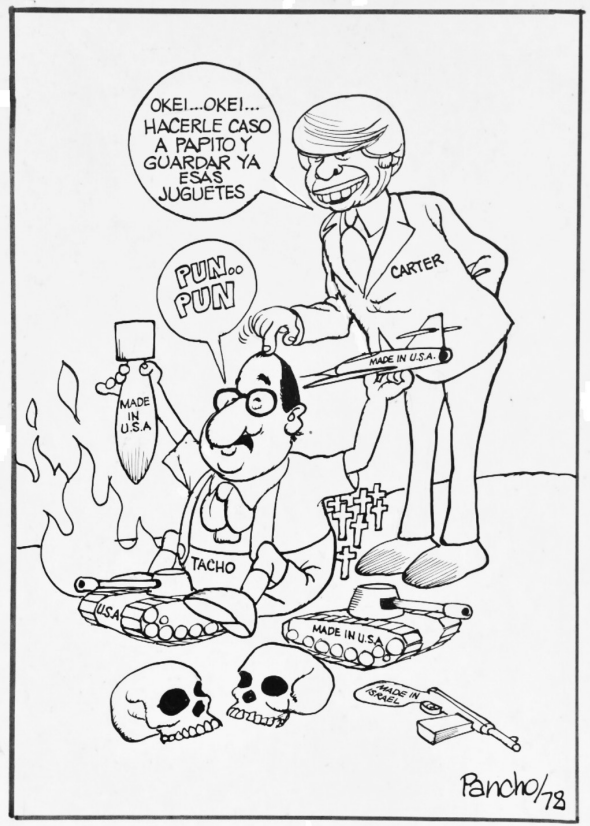

Fuente: UCR-CHD-2953, Museos UCR. 
La Figura 3 es quizás la imagen que mejor captura esa ambivalencia en la política exterior de los EE. UU. en relación con el régimen somocista. En ella, Somoza juega como un niño con bombas y tanques de guerra que llevan de nuevo la inscripción "Made in USA". En este caso Jimmy Carter con su característica sonrisa se limita a fustigar al pequeño niño con palabras suaves: "hacerle caso a papito y guardar estos juguetes".

A razón de esto es evidente que Hugo Díaz es crítico de la pretendida actitud cautelosa de Carter y prefiere más bien resaltar la larga de historia de tolerancia y financiamiento militar que los gobiernos estadounidenses sostuvieron para con regímenes autoritarios en Centroamérica como el caso de Nicaragua. Sobre el apoyo de Carter, Waldmann afirma que

no existe la menor duda de que el respaldo que Washington prestó al régimen, durante décadas, a causa de la postura anticomunista de este, aumentó considerablemente su estabilidad... Por otro lado, justamente, esa actitud servil de los Somoza hacia los EE. UU. era la que justificaba el reproche que se les hacía de ser cómplice del imperialismo norteamericano (8).

En este sentido, Díaz era bastante crítico del apoyo financiero que nutrió la contienda de la Guerra Fría, como lo afirma Robert Higgs al argumentar que un "high base level of defense spending during the Cold War resulted from the dominant ideology of global anticommunism" [El alto nivel del gasto en defensa durante la Guerra Fría fue el resultado de la ideología dominante del anticomunismo global] (308).

Por su parte, para el experto Charles S. Maier:

"domination meant constructing an economic bloc of centrally planned economics that was designed to resist the seduction of the Mashall Plan and reemerging West European capitalism... -in USA it-meant helping to modernize its allies economies and to integrate as much as practical the residues of older imperial economic zones into a sphere of trade and exchange that posed no barrier to United States economic doctrines or ambition" [dominar significaba construir un bloque económico de economía planificada centralmente que estaba diseñado para resistir la seducción del Plan Mashall y a resurgir el capitalismo de Europa occidental... -en EE. UU.- significaba ayudar a modernizar las economías de sus aliados e integrar tanto como fuera posible, los residuos de las zonas económicas imperiales más antiguas en una esfera de comercio e intercambio que no planteaba barreras a las doctrinas o ambiciones económicas de los Estados Unidos] (45).

La asistencia económica estadounidense alimentó y aumentó la rapacidad de gran cantidad de regímenes autoritarios en todas latitudes, no solo en Latinoamérica. Estos analistas citados, entre otros, han demostrado la considerable importancia financiera que representó el gasto militar de EE. UU. para apoyar regímenes 
anticomunistas: las cantidades de dinero entregadas son tan astronómicas que hacen poner en duda qué tan "fría" fue esta contienda, si se toman en cuenta la cantidad de conflictos avivados por la política exterior estadounidense.

En las caricaturas, la siguiente administración del presidente Reagan es representada en las caricaturas de Díaz como un padrino fundamental del sostenimiento del movimiento contrarrevolucionario o "La Contra" en la frontera norte del territorio de Costa Rica. A razón de esto el historiador Hobsbawm afirma que

la politica de Ronald Reagan, sólo puede entenderse como el afán de lavar la afrenta de lo que se vivía como una humillación, demostrando la supremacía y la invulnerabilidad incontestables de los Estados Unidos con gestos de fuerza militar contra blancos fáciles... acaso porque era un actor del montón, comprendió el estado de ánimo de su pueblo y la hondura de las heridas de su amor propio (251).

Ronald Reagan se representa en imágenes que aparecerán a lo largo de veinte años, como un gran apoyo para La Contra, en algunas caricaturas viste con una camisa que dice "I am a Contra" (Soy un Contra) y más adelante "I was a contra" [Yo era un contra]. Tómese por ejemplos las siguientes imágenes que datan de 1986 (Figura 4), 1992 (Figura 5) y 1993 (Figura 6):

Figura 4

YO TAMBIÉN SER UN CONTRA!, 1986, TINTA CHINA EN CARTULINA

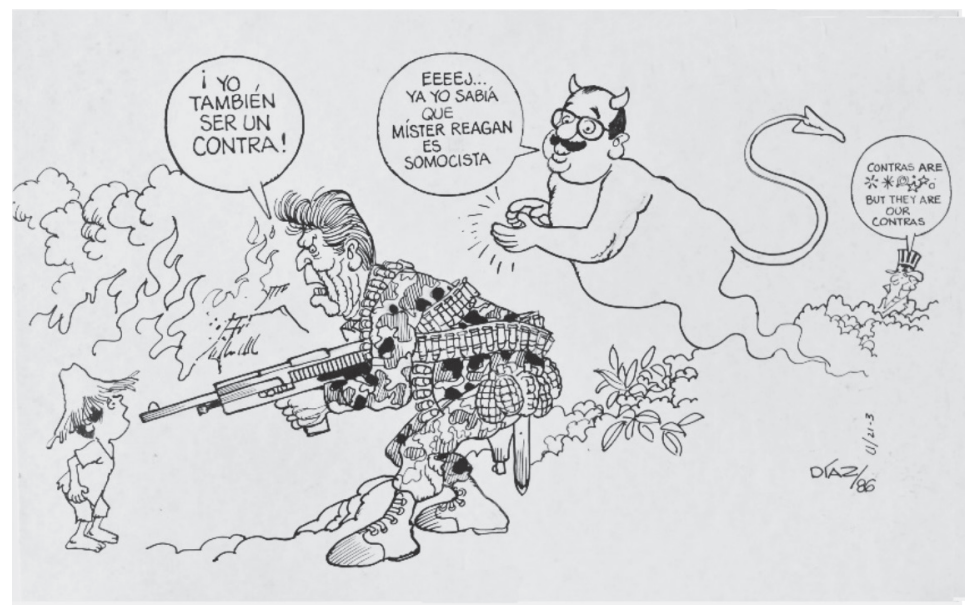

Fuente: UCR-CHD-1624, Museos UCR. 
Figura 5

I WAS A CONTRA, 1992. TINTA CHINA EN CARTULINA

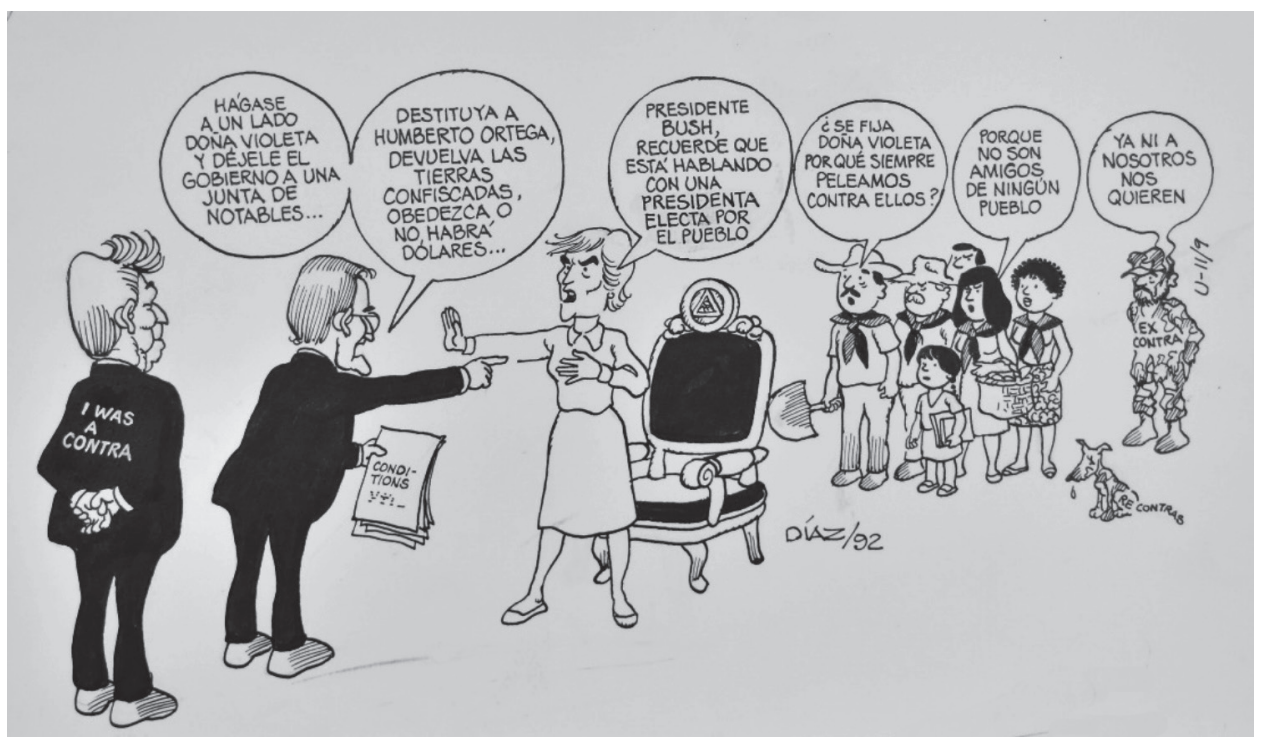

Fuente: UCR-CHD-1419 y 1835, Museos UCR.

Figura 6

SIGUEN LAS DISPUTAS POR LA FINCA SANTA ELENA, 1993. TINTA CHINA EN CARTULINA

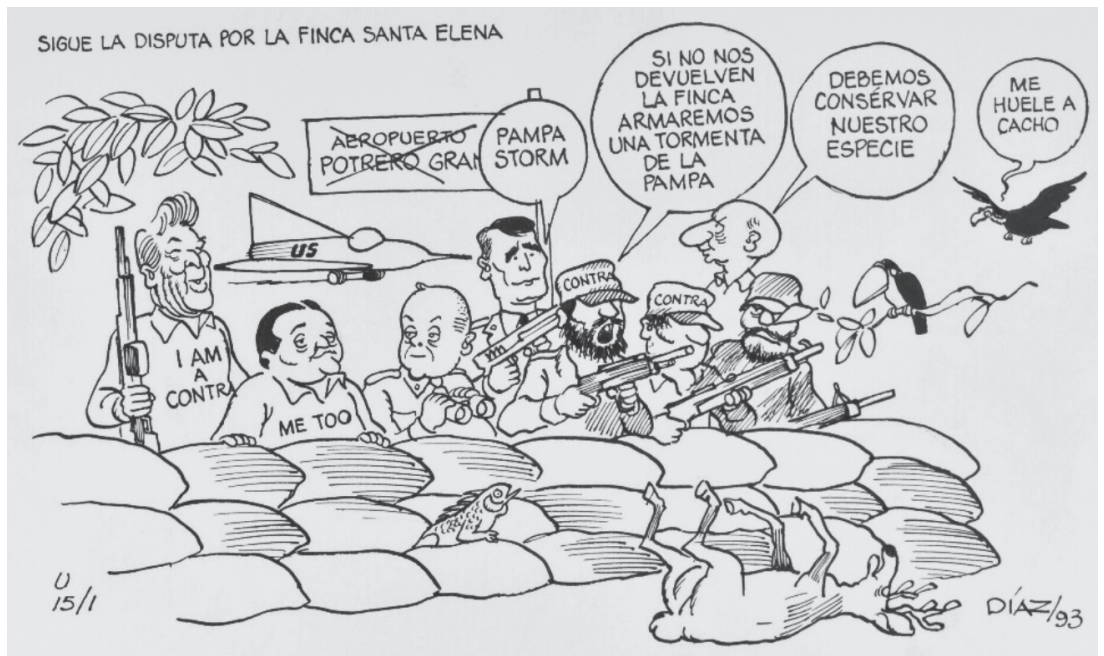

Fuente: UCR-CHD-1419 y 1835, Museos UCR. 
En la Figura 4 el presidente Reagan amenaza a un hombre pequeño que porta un chonete, quien a cambio lo mira con confusión. Detrás de él flota en el aire Somoza, como un genio malvado mientras dice "Yo sabía que mister Reagan es somocista". Detrás de Somoza aparece otro personaje fundamental en la iconografía de la caricatura antiimperialista regional: el Tío Sam. El Tío dice nada más “Contras are $\$ \% \$$ but they are our Contras". Así el Tío Sam es evocado en esta imagen vinculandolo a la historia de injerencia de la potencia del Norte, en los asuntos de la región. El emblemático Tío posee una historia iconográfica singular en las representaciones antiimperialistas latinoamericanas, donde aparece "sistemáticamente como un personaje hostil, prepotente y siempre dispuesto a utilizar el engaño" (Pinyol Vidal 21).

La postura de Reagan y EE. UU. con relación a Centroamérica, se basó en la creencia de que el problema de la región y Nicaragua en particular no tenía que ver con procesos de desigualdad y gobiernos autoritarios de larga data, sino al virus externo del comunismo, propagado e instigado por los soviéticos y sus agentes cubanos. El presidente advirtió que por medio de la creación de regímenes marionetas en Centroamérica, Moscú y La Habana pretendían cortar la comunicación de Estados Unidos con el resto del mundo. Lo que se necesitaba para combatir la amenaza no era más ayuda económica, sino ayudar militarmente a los elementos antimarxistas de la región (Powaski 289).

A su vez, en las anteriores representaciones (Figura 5 y Figura 6) Reagan es siempre identificado por su apoyo material al movimiento que intentaría desmovilizar a la Revolución sandinista. A lo largo de toda la administración del presidente estadounidense, Díaz lo muestra armado con artillería pesada. Posteriormente, hacia los noventas una vez que Reagan no es más presidente, el artista lo sigue identificando con la CIA y La Contra. Reagan entonces no aparece como un militar involucrado en el conflicto nicaragüense directamente, sino que le viste con un traje ejecutivo.

Sobre la figura de la injerencia estadounidense en el suelo Centroamericano, debe hacerse la salvedad de que el discurso de Díaz es complejo, ya que por un lado se sanciona la intromisión del Tío Sam, pero por otro lado manifiesta cierta fascinación con la cultura norteamericana de principio de siglo, paralelamente a la absoluta indignación del caricaturista con las políticas exteriores dirigidas por los Estados Unidos hacia Costa Rica y sus naciones vecinas. Este fenómeno de fascinación con la cultura norteamericana ha sido bien estudiado; gracias a analistas sobre el antiimperialismo en el continente como Jussi Pakkasvirta, ha sido posible determinar que "no hay tal cosa como un antiimperialismo dual (blanco y negro), sino que éste se constituye en un tenso fenómeno de admiración y disgusto, un proceso de aceptación y de crítica, pues el pensamiento intelectual antiimperialista es complejo y el arte contribuye a desnudar y a exponer (sus) diferentes facetas" (Vindas Solano, 145).

Ejemplo de ello es la Figura 7. Haciendo uso del formato de historieta, Hugo Díaz trata de proponer una lectura que devela su compleja relación con la figura de los EE. UU.: en esta historieta, se distancia al "imperialismo" del Norte, de los ideales 
políticos de los padres fundadores del Estado norteamericano y de aquellos dirigentes reconocidos por su lucha antiesclavista. La caricatura se llama "una cosa es el imperialismo y otra cosa es el pueblo norteamericano".

Figura 7

UNA COSA ES EL IMPERIALISMO Y OTRA COSA ES EL PUEBLO

NORTEAMERICANO, 1977. TINTA CHINA

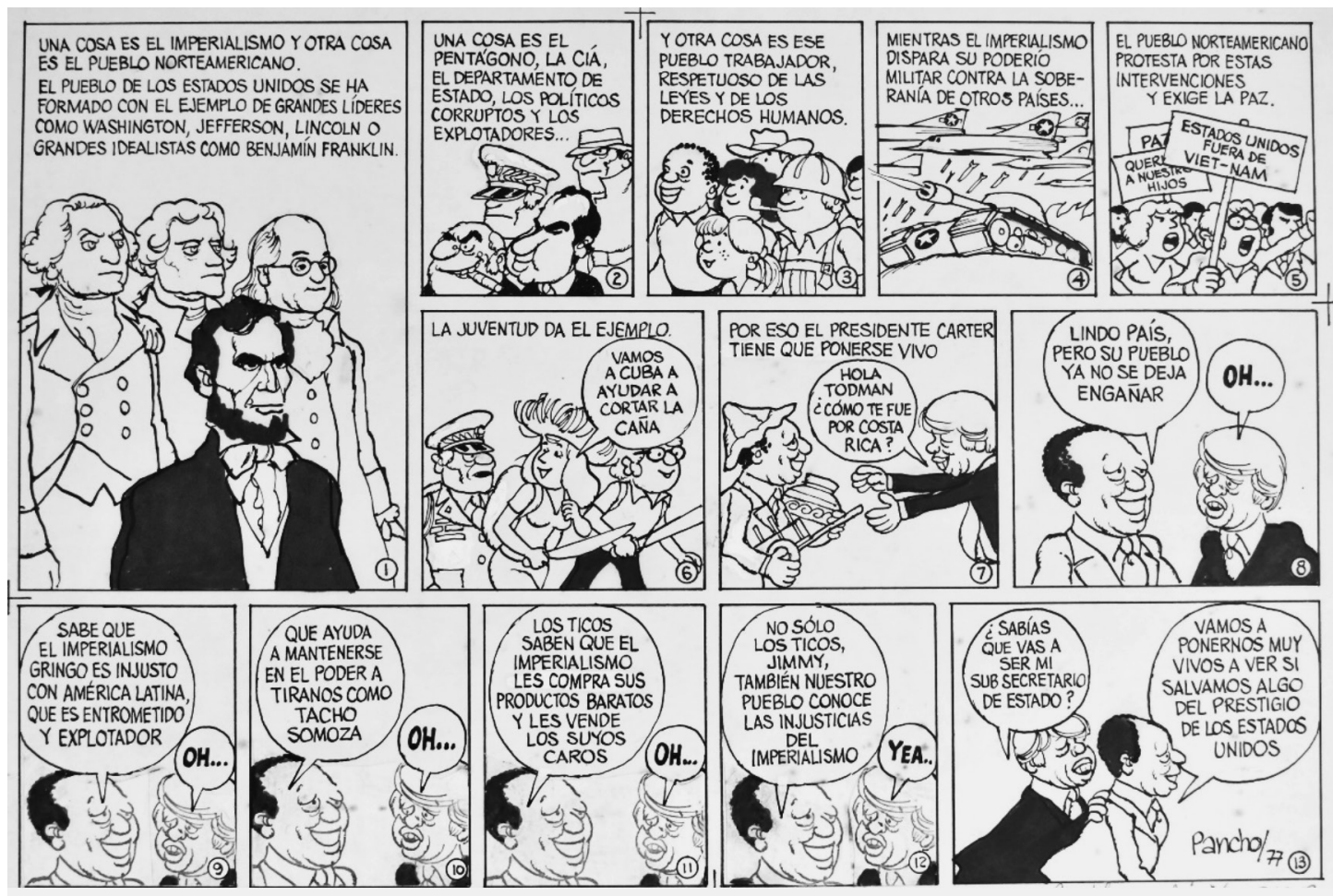

Fuente: UCR-CHD-2939, Museos UCR.

En la Figura 7 los expresidentes norteamericanos liderados por Abraham Lincoln le llaman la atención a Jimmy Carter diciendo, "por eso el presidente tiene que ponerse vivo", ya que "mientras el imperialismo dispara su poderío militar contra la soberanía de otros países, el pueblo norteamericano protesta por estas intervenciones y exige paz". Por su parte, un grupo de personas sostiene pancartas que dicen "Estados Unidos fuera de Viet-nam". Díaz continúa "Los ticos saben que el imperialismo les compra sus productos baratos... vamos a ponernos muy vivos a ver si salvamos algo del prestigio de los Estados Unidos".

En el caso costarricense, como ya se ha mencionado, la aparición de los presidentes Oduber, Carazo y Arias en las caricaturas es mucho menor en cantidad que 
la del presidente Luis Alberto Monge, para el periodo de estudio. Sin embargo vale la pena revisar una de las caricaturas que se encontró sobre el presidente Rodrigo Carazo, ya que representa a un personaje adicional muy particular: el expresidente costarricense José Figueres Ferrer.

Su inclusión en el corpus de caricaturas sobre el tema resulta interesante puesto que Díaz presenta la aparición de este exmandatario costarricense, como un ente que sanciona a los militantes de tanto el Partido Liberación Nacional (partido que fundó Figueres) como el Partido Social Cristiano (partido de oposición), pues no está satisfecho con las acciones de ambos bandos. Pero lo que más se destaca de las breves apariciones de Figueres en las caricaturas (unas 3 caricaturas se registran sobre él vinculado al tema), es la inquietud que demuestra el expresidente por volver a ser mandatario, ya había sido presidente en dos ocasiones en 1953 y 1970. Díaz parece burlarse de sus sanciones por pensar que él siendo presidente por tercera vez haría las cosas mejor.

Figura 8

TOTAL RESPALDO DE FIGUERES A CARAZO, 1981. TINTA CHINA

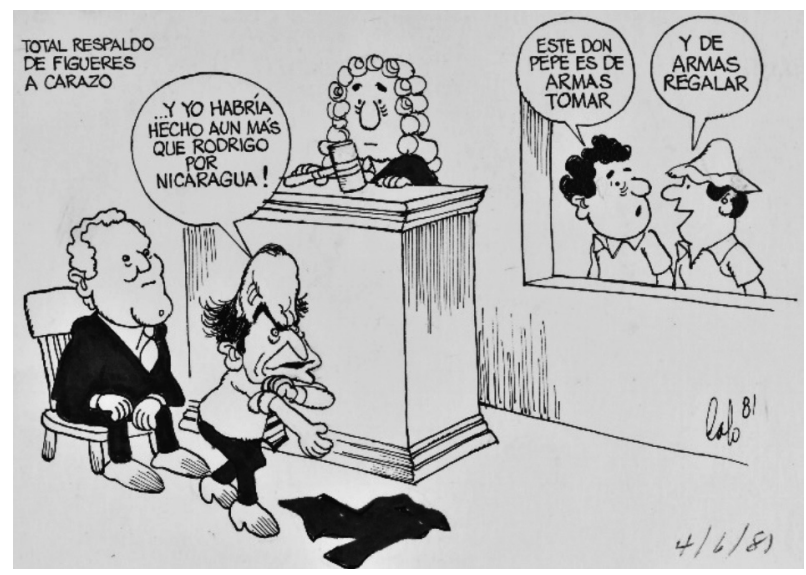

Fuente: UCR-CHD-3928, Museos UCR.

Por su parte, la figura del presidente Rodrigo Carazo aparece reiteradamente, esto no es casualidad, pues era presidente durante el estallido de la Revolución en Nicaragua (1978-1982). El propio Carazo posterior a este episodio se reconstruye a sí mismo ante la Organización de Estados Americanos (OEA), como una figura central de la contienda en Nicaragua por haber propiciado el cese de presiones estadounidenses contra Nicaragua. En sus memorias, habla de cómo el expresidente José Figueres consideraba que Jimmy Carter no estaba siendo lo suficientemente firme para terminar con la amenaza somocista. En las caricaturas de Díaz, Carazo y Figueres aparecen juntos, 
casi compitiendo por el protagonismo como líderes de la Costa Rica "neutral". Así, en la Figura 8 Díaz satiriza esta postura de Figueres Ferrer, y le pone a decir "Yo habría hecho aún más que Rodrigo por Nicaragua".

Las representaciones que hace Díaz de la figura del presidente José Figueres son todo un ámbito abierto a la investigación. Esta caricatura es un ejemplo de la manera en que el artista comentó las acciones de este exmandatario, quien le pareció una figura enigmática por su carácter polémico y "travieso" (Díaz, 1992). En la entrevista en que participa en los noventa, Hugo Díaz afirma que la razón por la que representó tanto a actores como "Pepe" Figueres, fue porque "las cosas que don Pepe hacía que muchas veces estaban matizadas de muy buen humor" (1992), lo cual lo hacía sujeto idóneo para sus caricaturas.

Díaz fue muy crítico con la postura contradictoria que toma Costa Rica en este conflicto: por un lado, parece declararse neutral en medio del conflicto, pero por otro lado no hace nada por detener la articulación de La Contra en la frontera Norte del suelo costarricense. Ejemplo de ello es la Figura 9: en ella Somoza se posiciona sobre el mapa de Costa Rica y comenta "Cho jodido ya es hora de empezar a mover los amigos que tengo en Costa Rica". Esta es una crítica contra de la pretendida "neutralidad costarricense" frente al conflicto de la Revolución sandinista y Díaz llama la atención sobre el rol que juegan los políticos en no frenar el poder que fue amasando Somoza.

Figura 9

CHO JODIDO YA ES HORA DE EMPEZAR A MOVER LOS AMIGOS

QUE TENGO EN COSTA RICA, 1978. TINTA CHINA

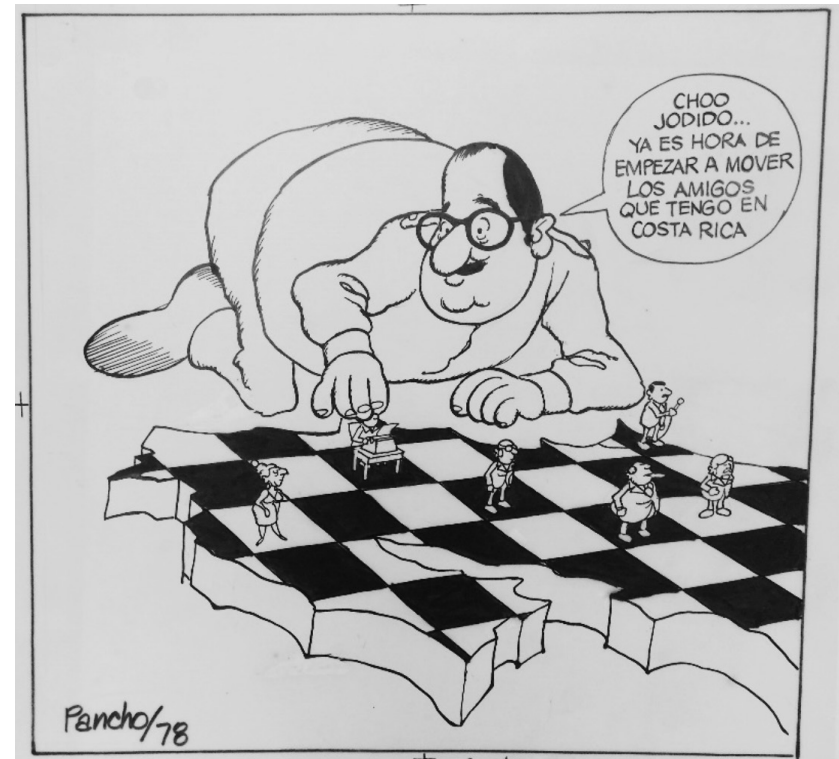

Fuente: UCR-CHD-3232, Museos UCR. 
La Figura 9 encapsula en una imagen un importante proyecto político y artístico que desarrolló Díaz a través de sus caricaturas, al ser un maestro en descubrir la realidad que ocultan las "mentiras consoladoras de los discursos oficiales" (Anglin Fonseca 88). El artista "lejos de idealizar la sociedad de los años 70, se concentró en escudriñar los problemas sociales que todavía quedaban por resolver, y atacó frontalmente el mito de la "excepcionalidad costarricense" (Anglin Fonseca 86).

Trabajó también por desmitificar mitos democráticos del país, como la postura de superioridad que adopta Costa Rica con relación a sus vecinos centroamericanos. Díaz calificó esta actitud como una actitud de "vanagloria", ya que en Costa Rica

creemos que somos el mejor país de Centroamérica, que somos el país más culto, el país más instruido, que nuestra gente es mejor, que mejor estamos solos: cerca de Centroamérica pero de cierta forma aislados, [sin] formar parte del Parlamento Centroamericano porque nosotros tenemos otra forma de pensar, otra filosofía de la libertad y de pensamiento político, eso yo diría que son cosas que no conducen a nada (Díaz, 1992).

Después de Carazo en 1982, Luis Alberto Monge llega al poder como presidente de la República de Costa Rica. Díaz es igual de severo con Monge que con el presidente anterior y en la Figura 6, se le puede ver situado junto a Ronald Reagan quien lleva una camisa que dice "I am a Contra/Soy un contra". A su costado, Monge porta una camisa que dice "Me too/yo también", Díaz por tanto es claro en su lectura: llama la atención sobre la postura hipócrita de los mandatarios que se hicieron llamar neutrales, sin embargo en su opinión, parece que tienen un nivel de responsabilidad importante en la consolidación de La Contra en Centroamérica como los Estados Unidos.

Para Díaz, Monge había flexibilizado la frontera Norte para permitir la actividad del movimiento de La Contra. Luis Alberto Monge empero difundió la noción de que Costa Rica se mantenía al margen de la contienda, mediante textos como la "Proclama de neutralidad perpetua, activa y no armada" difundida en Noviembre de 1983. Sin embargo, no solo se flexibiliza el país en términos territoriales, sino que según Edelberto Torres Rivas, Costa Rica ganó la "simpatía norteamericana por un régimen que se oponía al sandinismo. Costa Rica recibió entre 1982 y 1988 un millón diario de dólares como apoyo político y económico" (165). Pérez Yglesias ha caracterizado la política de Monge como "entreguista" (160), también en la prensa de la época se le tildó de "servil" (Díaz Arias 203) con los Estados Unidos, pues la articulación de La Contra en la frontera costarricense era de conocimiento público en la prensa de la época.

Para historiadores como Díaz Arias, esta postura de neutralidad era abiertamente ambigua y pasiva. Esta actitud fue bastante criticada, y sirvió como base del discurso político del candidato presidencial que ganaría las siguientes elecciones: Óscar Arias Sánchez, quien manifestó: 
Me propongo no sólo tener una posición pasiva, de no dejarnos arrastrar a ser actores en los conflictos que viven pueblos hermanos, sino que, por el contrario, queremos tener una posición activa, hacer de Costa Rica un agente promotor de la paz en Centroamérica y el mundo (Díaz Arias 195).

Vale la pena recalcar que el debate sobre la pasividad y la falta de neutralidad de Costa Rica no fue una crítica que se limitó a la figura de Carazo o Monge, sino que era algo que ambos partidos oficialistas de la época se criticaban mutuamente, ya "para mitad de 1985, en la propaganda electoral el PUSC y el PLN comenzaron a acusarse mutuamente por haber apoyado al sandinismo en 1979" (Díaz Arias 193).

En la Figura 10, Díaz representa al entonces expresidente Luis Alberto Monge en Miami hacia 1994. Monge mira en el televisor la situación que se estaba desarrollando en torno al bloqueo económico de los EE. UU. frente a Cuba. Desde 1992, la potencia había estado implementado sanciones económicas contra Cuba como "The Cuban Democracy Act" de 1992. Lo que interesa de la caricatura con relación al personaje, es resaltar la pequeña bandera con la que Hugo Díaz adorna la habitación de Monge: sobre la cabeza del personaje se puede ver una bandera triangular que dice "CIACONTRA". Esta decoración se asemeja a los souvenirs que coleccionan los seguidores de un equipo deportivo. En este caso el banderín, un motivo tan pequeño y simbólico presente en el dibujo, implica que Monge fue sino colaborador al menos fanático del "equipo" CIA-Contra.

Figura 10

MONGE, 1994. TINTA CHINA

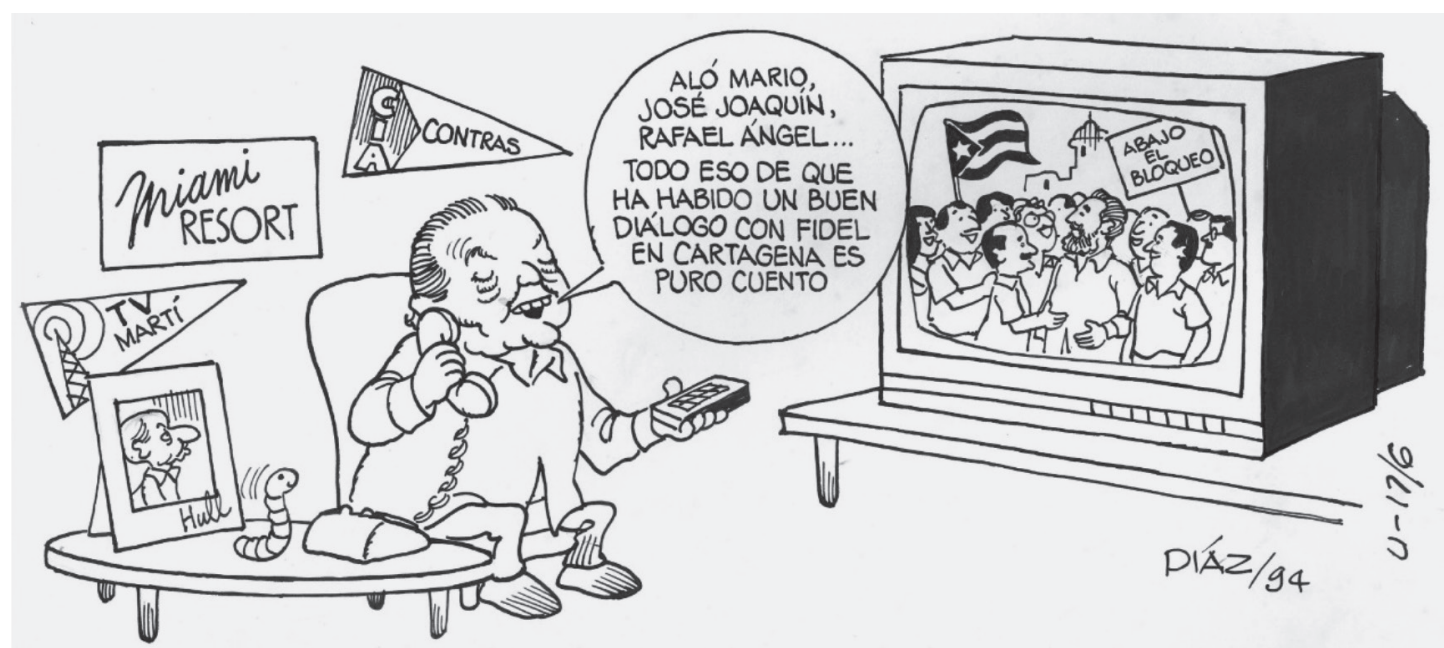

Fuente: UCR-CHD-481, Museos UCR. 
La representación de personajes vinculados a las políticas exteriores de la Unión Soviética en la caricatura de Díaz es menos abundante que aquellas relacionadas a los Estados Unidos. Se registran algunas valoraciones del artista sobre la dirigencia de la URSS, por lo que si bien no dibujó qué pensó sobre la posible injerencia o no de Rusia en Nicaragua, sí comenta por otro lado, sus apreciaciones sobre lo que sucede en el mundo soviético. Las pocas imágenes que se encuentran sobre la URSS permiten analizar algunos elementos sobre la postura que tiene el artista con relación de la política de los soviéticos y la Revolución sandinista.

Se encontraron 3 imágenes sobre el tema de la Guerra Fría dos que corresponden a 1998 y el 2000 -en las cuales Díaz realiza una remembranza de lo que fue la caída de la URSS-, así como la siguiente historieta:
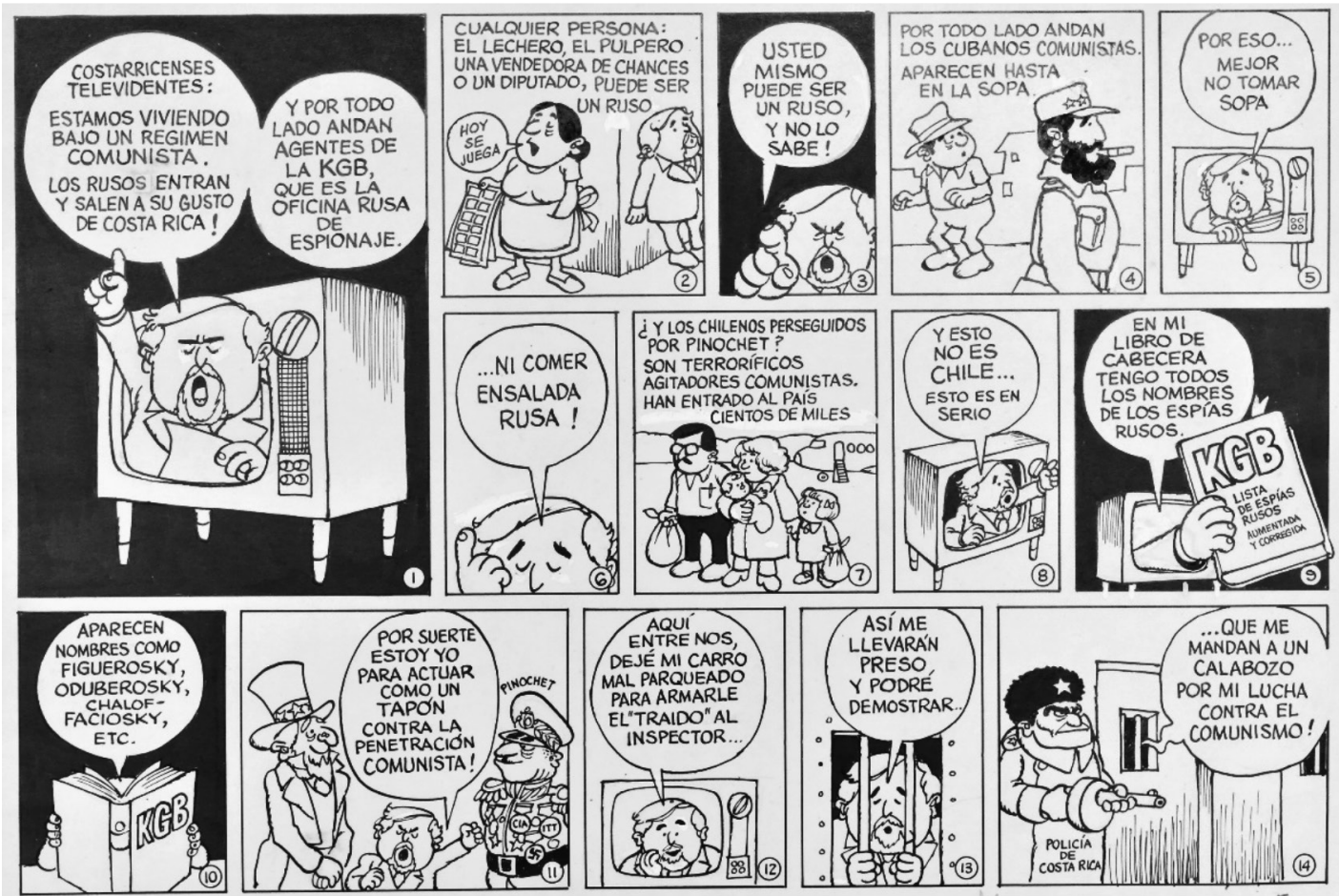

Fuente: UCR-CHD-1738, Museos UCR.

La Figura 11 es la única caricatura en la que se encuentra una referencia específica a la URSS en la región centroamericana. La imagen hace alusión a los imaginarios 
asociados a la paranoia anticomunista en los medios de comunicación, en este caso a través de la televisión, ya que en el dibujo un presentador de televisión insta a los costarricenses diciendo "los rusos entran y salen a su gusto de Costa Rica... en mi libro de cabecera tengo todos los nombres de los espías rusos aparecen nombres como Figuerosky, Oduberosky, Chalofaciosky, etc.".

Díaz hace una burla jugando con los nombres de expresidentes tales como Figueres y Oduber, señalando la paranoia existente de la influencia soviética sobre los políticos centroamericanos. Hay otro elemento interesante en la caricatura, si se mira al presentador, junto a este aparece el Tío Sam en actitud de aprobación, en su lucha contra la "penetración comunista". Díaz critica por un lado, el servilismo de los líderes políticos de Costa Rica ante las potencias extranjeras como EE. UU., pero también el conflictivo pasado nacional con relación al anticomunismo vivido en la sociedad costarricense, posterior a la guerra civil de 1948. Estos eran temas que apasionaban a Díaz, él fue enfático al decir que algunos temas que le preocuparon a lo largo de su carrera se relacionan con la injerencia cultural y política de potencias internacionales y la pérdida de autonomía de los países latinoamericanos ante ello, así como el peso de la influencia cultural norteamericana en nuestras culturas (Díaz, 1992).

Por otra parte, en la siguiente imagen el artista realiza un resumen gráfico del año 1976. En este, Díaz representa los principales personajes asociados a las historias que circularon en prensa dicho año. Lo interesante es que esta caricatura es al mismo tiempo una introspección del propio artista sobre el trabajo que ha realizado y el contexto que ha estado comentando: este contexto que dibuja evidencia que el artista sabe que su producción artística está comentando un contexto de polarización profundo entre los EE. UU. y la URSS, inclusive aparece un actor que no saldría con asiduidad en sus caricaturas: Mao Tse Tung. 
Figura 12

1976, 1976. TINTA CHINA

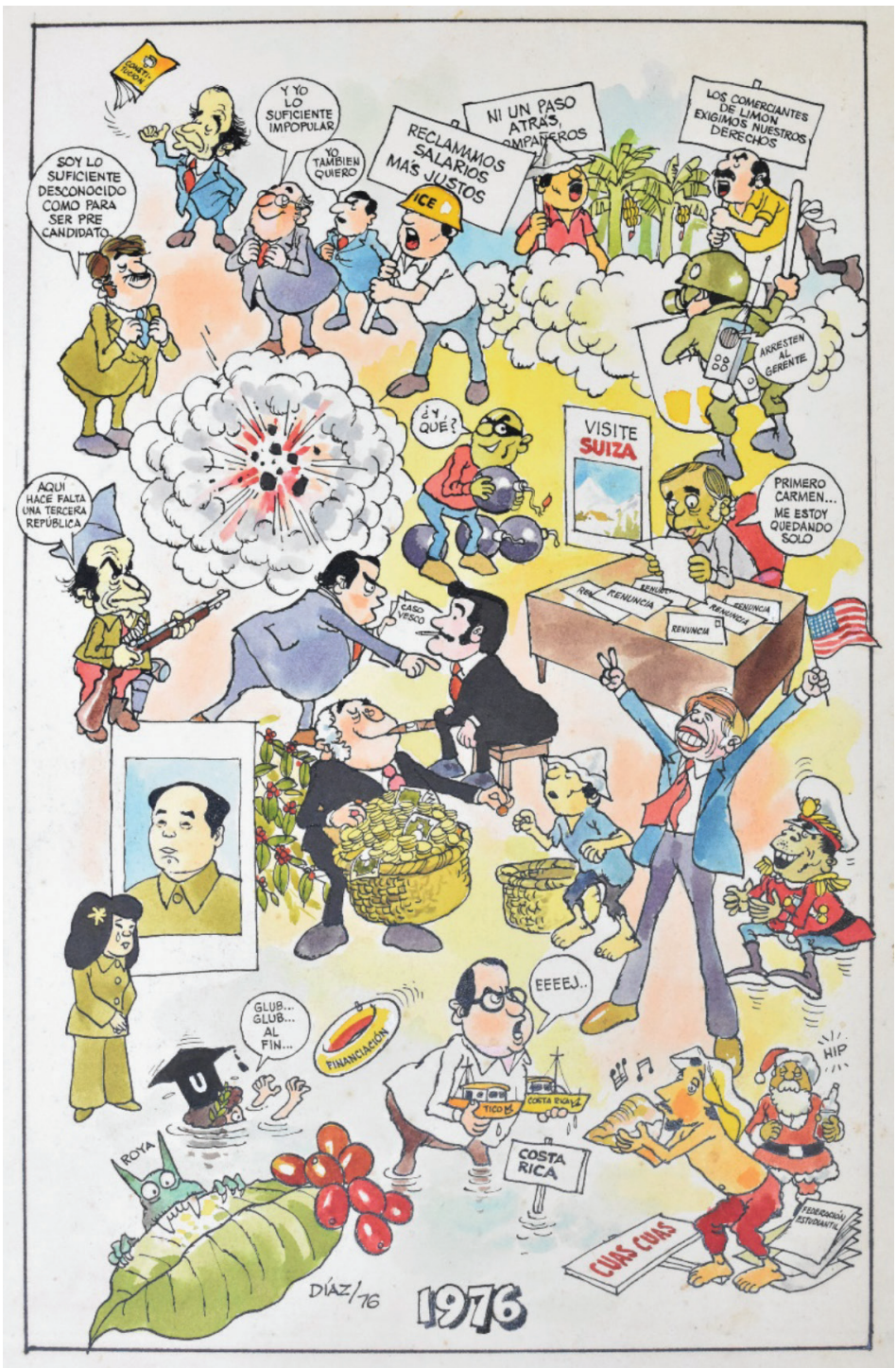

Fuente: UCR-CHD-3001, Museos UCR

Mao, en la Figura 12, está ubicado junto a los trabajadores del Instituto Costarricense de Electricidad (ICE), quienes resisten procesos de privatización y luchan por el mejoramiento del servicio eléctrico que vive el país para dichas épocas. Este contexto que comenta Díaz por tanto no solamente es un contexto de polarización 
política, sino de un cambio radical de modelo económico: la fundación de los cimientos de los estados neoliberales que comenzaron a desmantelar los avances de los Estados de Bienestar de las décadas anteriores, ya que para "1980 el modelo socialdemócrata tropical ya funcionaba mal y el neoliberalismo fue implantado por dos presidentes 'liberacionistas', Luis Alberto Monge (1982-1986) y Óscar Arias (1986-1990)” (Torres-Rivas 165). Estos temas sobre los problemas coyunturales del sistema político y la sociedad costarricenses preocuparon al artista.

Otro personaje en esta revisión anual es Jimmy Carter, que ondea la bandera de los EE. UU. y el mismo Somoza que sostiene buques de guerra, recordemos que en 1976 estamos a 3 años de la consolidación la Revolución sandinista. Figueres, también presente en el cuadro sostiene un arma que estalla mientras dice "Aquí hace falta una Tercera República", haciendo referencia al papel de Figueres en la construcción de un discurso sobre la consolidación de la "Segunda República" de Costa Rica, después de liderar la revolución que dio pie a la Guerra Civil de 1948.

A su vez, otro tema que es central para el artista es la crítica a la carrera armamentista que se da a lo largo de la contienda de la Guerra Fría. Aunque no se registran caricaturas que involucren este tema con la Revolución sandinista, es importante revisar algunas caricaturas que representan la interacción entre EE. UU. y la URSS puesto que aportan elementos para entender la postura de Díaz sobre el conflicto Nicaragüense. En ellas Díaz representa una compleja relación entre las potencias.

Por ejemplo, Díaz comenta los acercamientos entre las potencias en disputa (EE. UU. y URSS) casi diez años después en Noviembre de 1985, durante la reunión en Ginebra entre la Estados Unidos y la Unión Soviética. Esta caricatura resume lo que Powaski comenta sobre el inminente fin de la Guerra Fría en dicha época. Para el autor, con la convención de Ginebra:

Lo que hizo en realidad Gorbachov fue declarar que estaba dispuesto a poner fin a la guerra fría. Los dirigentes occidentales, sin embargo, con la excepción de la primera ministra británica, Margaret Thatcher, tardaron en aceptar la rama de olivo de Gorbachov. Reagan, de hecho, se resistió a los halagos de Gorbachov durante más tiempo que la mayoría de los líderes occidentales. La mayor parte de los observadores, y la propia Nancy Reagan, dijo que ésta contribuyó en gran medida a persuadir al presidente de mostrarse receptivo a Gorbachov. La señora Reagan creía que mitigar las tensiones de la guerra fría consolidaría el lugar de su esposo en la historia (311).

En la Figura 13, Díaz parece ilustrar este acercamiento. Sin embargo con una llamada de atención y quizás una actitud cautelosa sobre una guerra que aún podía volver a encenderse. La amenaza aparece en forma de una gran ojiva nuclear, que se posiciona al lado de Reagan y Gorbachov. Esta gran bomba pone en cuestión el apretón de manos que comparten los dos líderes a su derecha. 


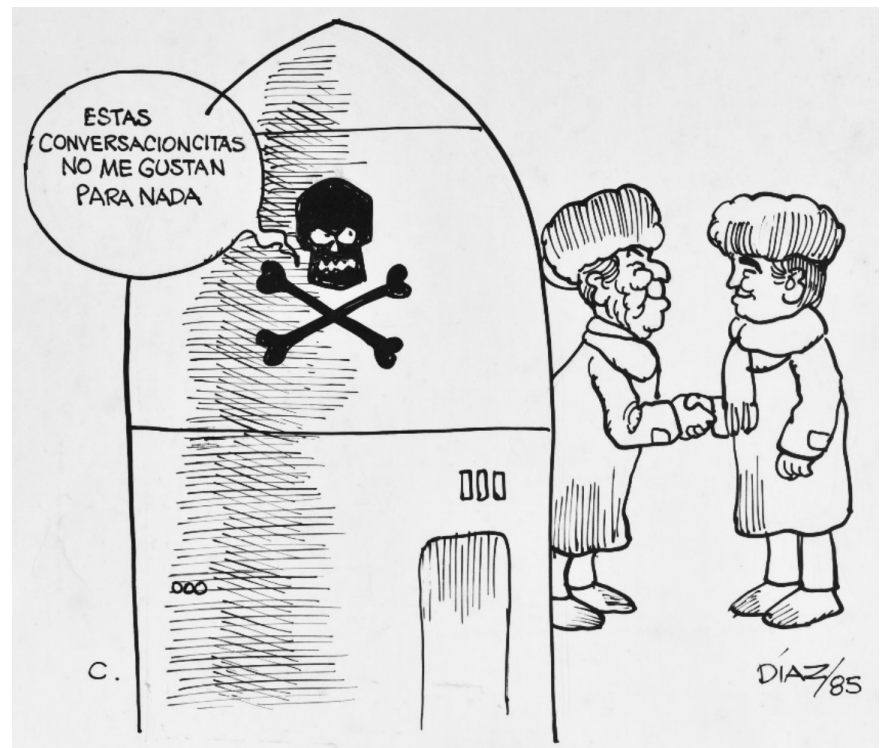

Fuente: UCR-CHD-3001, Museos UCR.

Sin embargo, los esfuerzos de Gorbachov no fueron en vano. El presidente de los EE. UU. volvería a evocar este espíritu de respeto entre la URSS y EE. UU. en los siguientes años. Hobsbawm es de la opinión de que el presidente estadounidense, "creía realmente en la coexistencia entre los Estados Unidos y la URSS, pero una coexistencia que no estuviese basada en un repugnante equilibrio de terror nuclear mutuo: lo que Reagan soñaba era un mundo totalmente libre de armas nucleares" (Hobsbawm 253). Para 1988 gracias a las presiones y esfuerzos del líder ruso, se habían empezado a alcanzar acuerdos para finalizar la guerra, Reagan mismo aceptó que la figura de Gorbachov fue central para lograrlo. En una entrevista televisiva que le realizan en 1988, se le preguntó

si seguía considerando a los soviéticos el "foco del mal en el mundo moderno", Reagan respondió: The Soviets have changed, not Reagan. Indeed, in that same television interview, the President declared, "I haven't changed from the time when I made a speech about an evil empire" [Los soviéticos han cambiado, no Reagan. De hecho, en esa misma entrevista televisiva, el presidente declaró: "No he cambiado desde el momento en que pronuncié un discurso sobre un imperio maligno"] (Shipler). 
Atribuyó el cambio en parte al liderazgo de Gorbachov y a la confianza que había nacido entre los dos dirigentes como resultado de sus cuatro encuentros en la cumbre. El presidente incluso abrazó al líder soviético en el mausoleo de Lenin; la periodista Maureen Dowd se refirió al abrazo en el New York Times diciendo

They could have been any middle-aged couple from out of town cuddling close together and watching the sunset over New Jersey [Podrían haber sido cualquier pareja de mediana edad de fuera de la ciudad abrazados y viendo la puesta de sol sobre Nueva Jersey] (1988).

La caída del bloque soviético es registrada por Hugo Díaz mediante no solo la caricatura que ya se analizó al comienzo de esta exposición, sino que también una imagen muy sugerente que aparece en 1991.

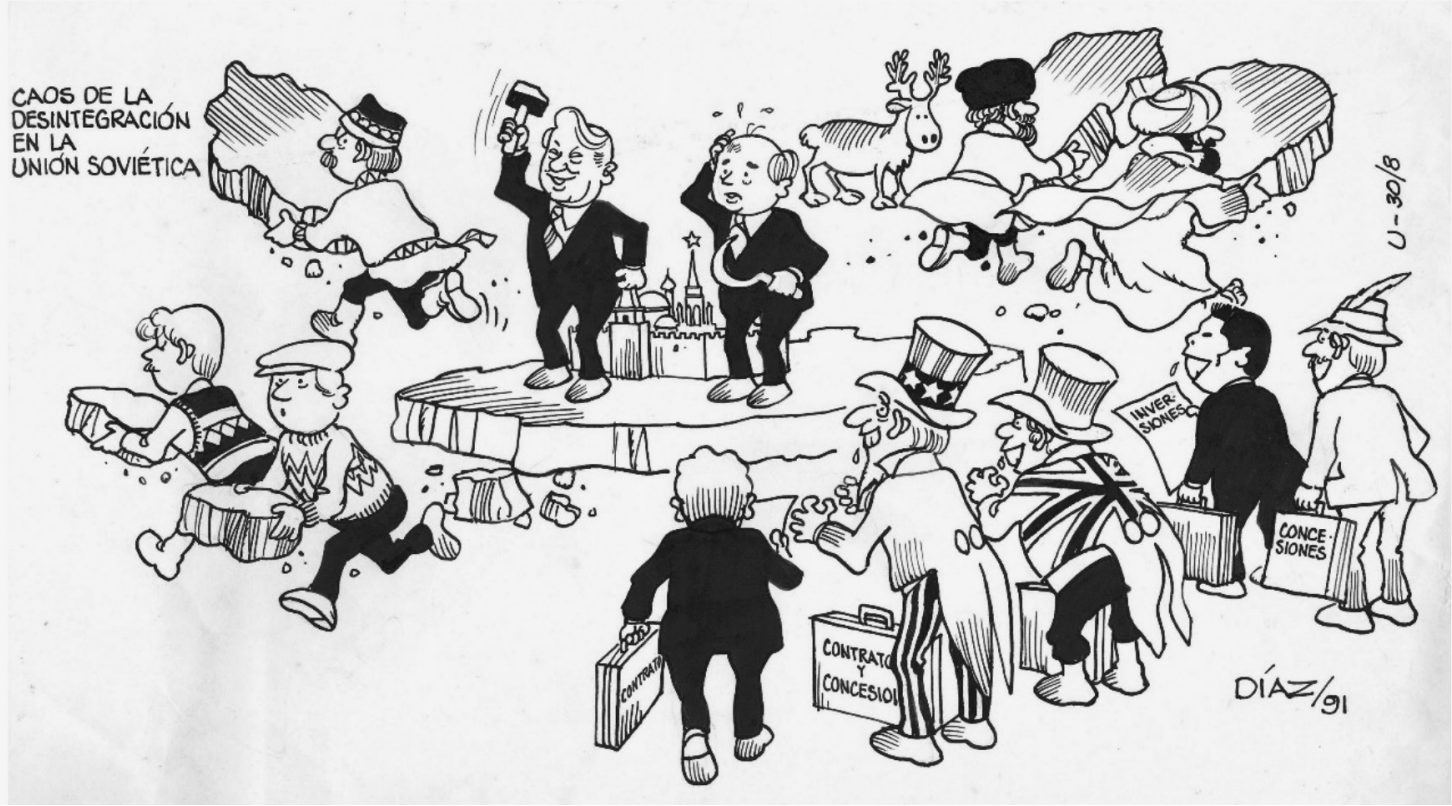

Fuente: UCR-CHD-799, Museos UCR.

En la Figura 14, Díaz logra captar el sentimiento de desmoronamiento e incertidumbre. En el dibujo, Gorbachov mira como diversas personas toman trozos de su territorio y corren en direcciones opuestas: La URSS había sido desmembrada. 
Adicionalmente el Tío Sam y el Reino Unido identificados con las banderas y la iconografía usual, esperan su turno para reclamar los trozos de la antigua Unión Soviética. El mismo Gorbachov reacciona con sorpresa ante la escena donde se resquebraja su nación. En otra caricatura, Díaz hace otro comentario sagaz: en la Figura 15, Gorbachov mismo se trae abajo el Kremlin. Mientras tanto, atrás Reagan y Bush miran con maravilla como se cae el edificio y con este, el busto de Lenin. El líder ruso lo tumbó con un mazo que sostiene con la mano izquierda, mientras se come una hamburguesa con la mano derecha.

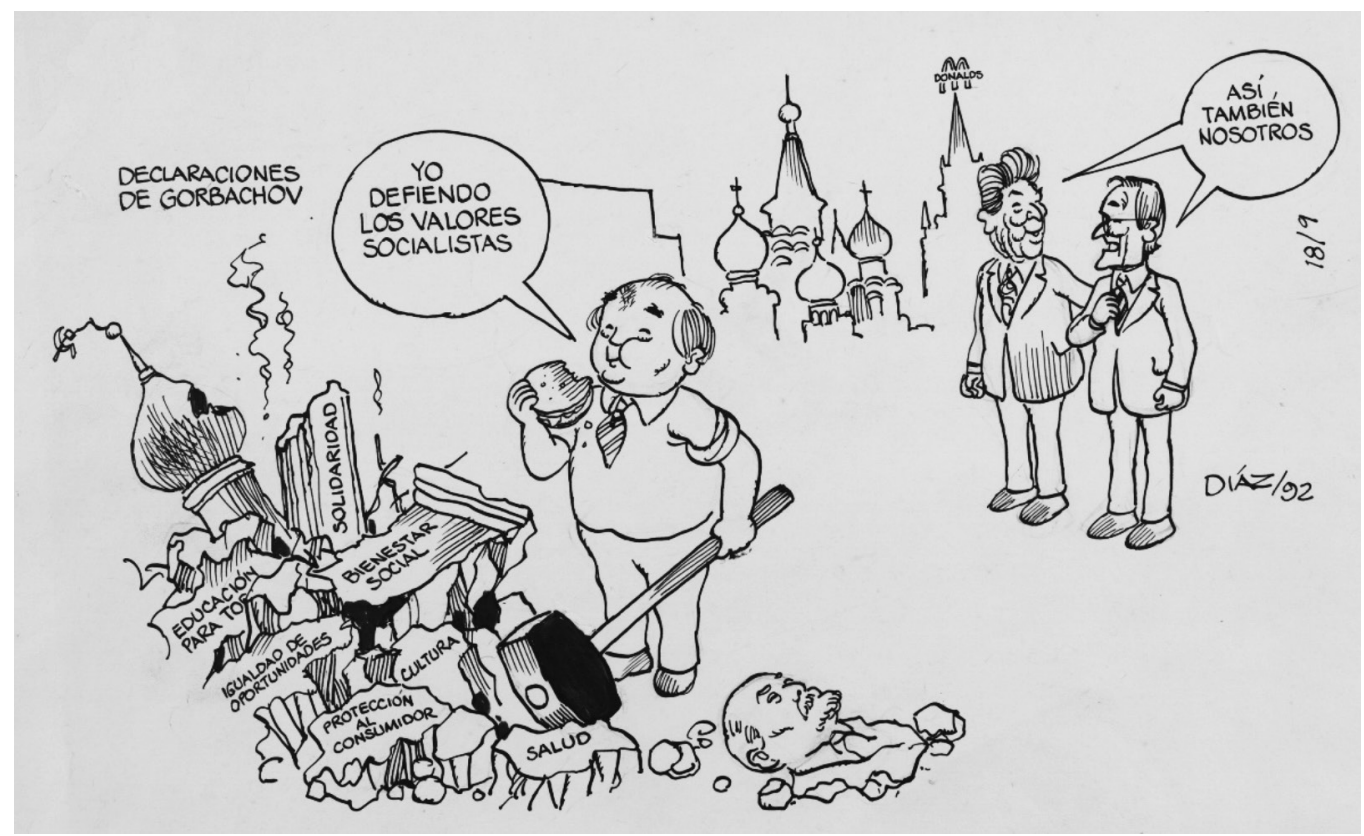

Fuente: UCR-CHD-199, Museos UCR.

Para la época, Gorbachov había puesto en práctica dos políticas fundamentales que aceleraron la caída del gigante soviético: la Perestroika y la política del glasnot. La lectura que realiza Díaz de este acontecimiento puede ser entendida a la luz de lo que explica Hobsbawm, sobre los efectos que estas dos políticas tuvieron sobre la ex Unión Soviética, para el autor

lo que condujo a la Unión Soviética con creciente velocidad hacia el abismo fue la combinación de glasnost, que significaba la desintegración de la autoridad, con una perestroika que conllevó la destrucción de los viejos mecanismos que hacían funcionar la economía, sin proporcionar 
ninguna alternativa, y provocó, en consecuencia, el creciente deterioro del nivel de vida de los ciudadanos (479).

En este sentido, Díaz es capaz de representar sintéticamente ese proceso de desarticulación geográfica y cultural en una imagen sobria, lúdica por excelencia y con información precisa como la Figura 15.

Estas imágenes aportan elementos que evidencian las complejas lecturas que realiza el artista, con relación a las potencias mundiales y señala las actitudes casi caprichosas de las políticas exteriores de estos países haciendo uso de la sátira y la hipérbole para subrayar el contexto político inmediato para Costa Rica y la región Centroamericana.

\section{Reflexiones finales}

En términos simbólicos, ¿cómo podemos entender de qué manera la Guerra Fría se vivió en nuestra región y qué actores protagonizaron dicha contienda? Una manera de hacerlo es a través del arte y el comentario social de la caricatura política. Así, ¿de qué manera artistas centroamericanos como Hugo Díaz trataron de proponer una lectura propia del conflicto? Estas han sido algunas de las inquietudes que guían esta investigación. Para María Pérez Yglesias, se debe entender la obra de Díaz "como una intertextualidad y como una práctica social, capaz de participar del arte y del compromiso con la historia" (Pérez Yglesias 23).

El contexto costarricense es convulso hacia finales del siglo XX: no solamente el país reacciona a los conflictos de los países cercanos, sino que a lo interno vive procesos de liberalización y privatización de bienes estatales que están generando resistencia en las calles y en las urnas. Para Rovira

tras el triunfo de la Revolución sandinista en julio de 1979... hubo un ascenso del movimiento guerrillero en la región en su conjunto. Incluso en Costa Rica en 1981 se abortó una incipiente guerrilla urbana y el movimiento partidario de izquierda, completamente legal y presente en las elecciones de 1982, experimentó agudas tensiones internas entre quienes, en virtud de la crisis politica regional a la que se sumaba la severa crisis económica costarricense de 19801982, se inclinaban por un crecimiento politico y electoral, por un lado, y quienes definían la situación como aquella largamente esperada en la cual habia que apurar las condiciones, que ya se insinuaban, para una eventual lucha revolucionaria, por otro (125-126).

Hugo Díaz representa estas tensiones internas en el país cuando realiza su comentario sobre la Revolución sandinista, aunque prefiere centrar su lectura en las acciones de las dirigencias políticas nacionales, para llamar la atención sobre la contradictoria postura de los presidentes costarricenses y las cúpulas de poder del país ante el conflicto.

Alfonso Chase explica, en la publicación "El Mundo de Hugo Díaz", por qué los personajes y mensajes de este artista siguen impactando a los lectores que encuentran su obra. Esto es debido a que sus personajes nacen 
de la entraña misma del pueblo, y porque antes que humorista Hugo Díaz es un hábil y tierno dibujante, cuya pluma recrea, por medio de trazos sutiles, los diferentes males nacionales... que además de expresar eso que llamamos el alma nacional, expresa también el alma del artista (Chase 11).

En términos de cómo lee el autor a los personajes asociados a la Revolución sandinista, Díaz parece identificar tres actores claramente distinguidos: Costa Rica (sus presidentes y Ministros, así como su pueblo), EE. UU. (mediante sus presidentes, estereotipos como Tío Sam y su pueblo), y la URSS fundamentalmente mediante la figura de Gorbachov. Este último actor sin embargo no es tan retratado en relación con el contexto de la Revolución sandinista como lo son los otros dos. Naturalmente esto responde a una injerencia más acrecentada y directa de la política exterior de EE. UU. -y la CIA- en la región.

Adicionalmente, como afirman Padilla y Ramírez sobre las imágenes que circularon en Europa con relación a las luchas armadas en Centroamérica, es claro que tanto los abanderados del capitalismo como aquellos afines a la lucha comunista pusieron en práctica retóricas visuales que fueron determinantes en el combate de la Guerra Fría, para "lo cual era necesario el uso de símbolos identificables para otra cultura, que dieran paso al mensaje connotado deseado" (Padilla y Ramírez 17). En este caso, en la retórica visual de Díaz pareciera ser que su apoyo al Sandinismo está implícito en las caricaturas. Por otro lado, Díaz no establece un vínculo intelectual entre el Sandinismo y el proyecto soviético, sino que casi que trata de darle una independencia ideológica y de caracterizarlo a través de sus opositores.

La figura de la URSS realmente no se considera central para el contexto de Hugo Díaz, como sí se considera la figura de EE. UU. El papel de los EE. UU. es el tema más importante en estas imágenes, pues las tres administraciones que abarcan el contexto de la Revolución sandinista -y su eventual triunfo- son bien representadas a lo largo de las caricaturas, en especial mediante una caracterización de la figura de La Contra en el suelo costarricense, así como de los presidentes norteamericanos, financiando la actividad de Somoza.

Costa Rica por otra parte, recibe tanto como EE. UU. el completo peso de la crítica de Hugo Díaz, para quien los presidentes costarricenses del periodo actúan con tolerancia al Somocismo y a la lucha anticomunista, en completa contradicción con la pretendida imagen de paz y neutralidad que se sostendrá con mayor fuerza a finales de la década de los 80, con los planes de paz liderados por Óscar Arias Sánchez. Los presidentes costarricenses Óscar Arias y Rafael Ángel Calderón, a pesar de que son presidentes en el lapso de estudio de esta investigación, no aparecen en caricaturas siendo vinculados a la discusión de la Revolución sandinista. Sí son retratados por otra parte, vinculados a discusiones que se llevan a cabo en la OEA, con relación a los procesos de paz en Centroamérica y con la designación de embajadores costarricenses en dicha institución. Vale la pena ampliar el análisis de esta temática en futuras investigaciones. 
Díaz como testigo de su época y como protagonista, es un excepcional relator, en la publicación "El Mundo de Hugo Díaz" Carlos Morales afirma que: "no es el caricaturista que lanza la piedra y esconde la mano, es el hombre que tiende la mano y guarda silencio" (Morales 14). El artista nos relata de manera lúdica y bastante clara qué sucede y por qué suceden las cosas que vivió, así como quienes son los responsables de ir moldeando la historia que él experimentó. "Su arte es llano y claro: la caricatura es un "arma para sacudir a la gente"... Hacer reír, pero provocando la reflexión" (Sánchez Molina, 2010). Es contundente cuando sienta responsabilidades y tampoco deja esconder su desconcierto y confusión en procesos como el del desarme nuclear de los ochentas y noventas. Como protagonista, Díaz parece externar su postura en sus caricaturas al mismo tiempo que cumple con un rol de cronista, al representarnos los eventos significativos del periodo de la manera más clara y sintética.

La carrera artística de Díaz se desarrolló a lo largo de más de tres décadas, por lo que su producción es amplia. Vale la pena que los historiadores e historiadores del arte sigan echando mano a fuentes como estas, creadas al calor del contexto por medio de la producción cultural de artistas de la época, de manera tal que se puedan matizar las lecturas teóricas que la academia realiza sobre los acontecimientos que estudia.

En esta breve investigación, queda claro que cada imagen sigue teniendo mucho por decir. En este texto se analizaron meramente 15 imágenes de un corpus de más de 100 obras de Díaz sobre el tema de la Guerra Fría y la Revolución sandinista; empero su legado es muchísimas veces superior en cantidad: la colección de la Universidad de Costa Rica cuenta con miles de caricaturas. Por tanto, no es exagerado decir que Hugo Díaz sigue siendo un campo abierto para la exploración estética e histórica y su legado, sigue esperando por ser descubierto.

\section{Nota}

1 Según disposiciones de MuseosUCR la correcta citación de cada imagen será "UCR-CHD-" más el número de catalogación. Por CHD se entiende: Colección Hugo Díaz.

\section{Bibliografía}

Anglin Fonseca, Lloyd. Corrientes estilísticas del humor gráfico costarricense 1981-2006. Universidad de Costa Rica, 2007. Recuperado de http://www.repositorio.ciicla.ucr.ac.cr:8080/ handle/123456789/2278

Brealey, J. J. La guerra no declarada. EUNED, 2006.

Carazo, R. Carazo: tiempo y marcha. EUNED, 1989.

Chaves, F. El análisis de contenido como ayuda metodológica para la investigación. Revista de Ciencias Sociales, 96, 2(2002). Recuperado de http://www.redalyc.org/articulo. oa?id=15309604

Cuban Democracy Act of 1992. Recuperado de https://1997-2001.state.gov/regions/wha/cuba/ democ_act_1992.html 
Díaz Arias, D. Enfrentar a Reagan y a La Contra: La opinión pública costarricense y la discusión por la paz en Centroamérica, 1986-1987. Memorias, 30, (2016): 189-218.

Díaz, Hugo. El mundo de Hugo Díaz. Editorial Costa Rica, 1977.

Dowd, Maureen. (8 de diciembre de 1988). The Gorbachev Visit; Soviet Star Is a Smash In Broadway Showing. The New York Times. Recuperado de https://www.nytimes. com/1988/12/08/world/the-gorbachev-visit-soviet-star-is-a-smash-in-broadwayshowing.html

Flores Valle, Laura. La representación del poder politico en tres caricaturistas costarricenses: José María Figueroa Oreamuno, Hugo Díaz Jiménez y Luis Demetrio Calvo. Universidad de Costa Rica, 2011. Recuperado de http://repositorio.ciicla.ucr.ac.cr:8080/browse?value= Flores+Valle $\% 2 \mathrm{C}+$ Laura\&type $=$ author

Gantús, F. La caricatura política y sus lectores. Ciudad de México, 1876-1888. Patrimonio y Memoria UNESP, 8, 1(2012): 4-26.

García, Dorde Cuvardic. La construcción de tipos sociales en el costumbrismo latinoamericano. Revista de Filología y Lingüística de la Universidad de Costa Rica, 34, 1(2008): 37-51. DOI:10.15517/rfl.v34i1.1648

Gatica, M. La discursividad en torno a la lucha armada sandinista a través del testimonio. Estudios, 29, (2014): 230-246.

Gombrich, Ernst Hans. La imagen y el ojo: nuevos estudios sobre la psicología de la representación pictórica. Debate, 2000.

Hobsbawm, E. J. Historia del siglo XX, 1914-1991. Grupo Planeta (GBS), 2000.

Kruijt, Dirk. Revolución y contrarrevolución: el gobierno sandinista y la guerra de la Contra en Nicaragua, 1980-1990. Desafíos, 23, 2(2011): 53-81.

Padilla, Fernando y Ramírez, Laura. Las imágenes de las guerrillas centroamericanas en las redes de la solidaridad internacional de Suecia. Naveg@mérica, 17, (2016). Recuperado de http://revistas.um.es/navegamerica/article/view/271901

Paraíso Almansa, Isabel. Las voces de Psique: estudios de teoría y crítica literaria. Universidad de Murcia, 2001.

Pérez Yglesias, M. La lucha por la paz en Centroamérica (1987) vista por la prensa y caricatura costarricenses. Anuario de Estudios Centroamericanos, 14, 1-2 (1988): 143-169.

Pérez Yglesias, M. La sociocrítica del sociohumor: La ironía en la risa popular. Revista de Filología y Lingüística de la Universidad de Costa Rica, 28, 2(2002): 185-200. DOI: 10.15517/ rfl.v28i2.4497

Pinyol Vidal, J. Imágenes y estereotipos iconográficos de América en las ilustraciones de la prensa peninsular de finales del siglo XIX. Amerika. Mémoires, identités, territoires, 14, (2016). Recuperado de https://amerika.revues.org/7298

Powaski, Ronald E. La guerra fría: Estados Unidos y la Unión Soviética, 1917-1991. Crítica, 2000.

Rocha, José Luis. La década de los años 80: Revolución en Nicaragua, revolución en la caficultura nicaragüense. Anuario de Estudios Centroamericanos, 29, 1(2003): 69-99.

Román, Gabriel. Fisiognomía y fealdad cómica en la caricatura política de Enrique Hine. LETRAS, 59, (2016): 155-182. DOI:10.15359/rl.1-59.7

Rovira, J. Centroamérica: Política y economía en la Posguerra (1944-1979). Diálogos Revista Electrónica, 6, 1(2011). Recuperado de https://revistas.ucr.ac.cr/index.php/dialogos/ article/view/6205

Sánchez Molina, A. C. (3 de octubre de 2010). La patria en Hugo Díaz. La Nación. Recuperado de http://www.nacion.com/archivo/patria-Hugo-Diaz_0_1150684940.html 
Sánchez Molina, A. C. (25 de mayo de 2016). Ese gran maestro don Hugo Díaz. Semanario Universidad. Recuperado de https://semanariouniversidad.com/suplementos/esegran-maestro-don-hugo-diaz/

Shipler, David K. (29 de mayo de 1988). Two Journeys; Reagan's Evolution: A Change of Heart as Well as Tatics? The New York Times. Recuperado de https://www.nytimes. com/1988/05/29/weekinreview/two-journeys-reagan-s-evolution-a-change-of-heartas-well-as-tatics.html

Torres-Rivas, E. La piel de Centroamérica: (una visión epidérmica de setenta y cinco años de su historia). FLACSO Guatemala, 2006.

Villafañe, J. y Villafañe Gallego, J. Introducción a la teoría de la imagen. Pirámide, 1985.

Vindas Solano, Sofía. Cerdos que se alimentan con oro: El imperialismo Yankee en las caricaturas costarricenses 1900-1930. ÍSTMICA, 21(2018): 95-148. DOI: doi.org/10.15359/ istmica.21.8

Waldmann, P. La revolución nicaragüense: la antigua y la nueva guerrilla de América Latina. Anuario de Estudios Centroamericanos, 12, 1(1986): 5-24.

Wilsman, A. R. Human Rights in the age of Cold War violence: The Central American example. Vanderbilt University, 2011. Recuperado de http://etd.library.vanderbilt.edu/available/ etd-03102011-094854/unrestricted/WilsmanHumanRights.pdf

Sofía Vindas Solano. Costarricense. Doctoranda en Historia por la Universidad de Costa Rica. Es máster en Ciencias Políticas y bachiller en Historia, así como en Historia del Arte de la Universidad de Costa Rica. Actualmente es investigadora del Instituto de investigaciones en Arte, a su vez es coordinadora del Repositorio de Patrimonio Cultural Centroamericano y es profesora de la Escuela de Historia de la Universidad de Costa Rica. Ha trabajado junto al Museo de Arte y Diseño Contemporáneo y el Museo del Banco Central en producción, investigación y curaduría desde el 2010. Ha sido profesora de la Universidad Nacional en la Escuela de Comunicación y Arte Visual e investigadora del Instituto de Investigaciones Sociales entre el 2010-2013.

Contacto: sofia.vindas@ucr.ac.cr

ORCID: 0000-0002-7618-282X 
